Eur. J. Mineral.

2017, 29, 1067-1082

Published online 9 June 2017

\title{
Nomenclature of the gadolinite supergroup
}

\author{
PETER BAČÍK ${ }^{1, *}$, Ritsuro MIYAWAKI ${ }^{2}$, DANIEL ATENCIO ${ }^{3}$, FERNANDO CÁMARA $^{4,5}$ and JANA FRIDRICHOVÁ ${ }^{1}$
}

\author{
${ }^{1}$ Department of Mineralogy and Petrology, Faculty of Natural Sciences, Comenius University in Bratislava, \\ Mlynská dolina, Ilkovičova 6, 84215 Bratislava, Slovak Republic \\ *Corresponding author, e-mail: bacikp@fns.uniba.sk \\ 2 Department of Geology and Paleontology, National Museum of Nature and Science, 4-1-1 Amakubo, \\ Tsukuba 305-0005, Japan \\ ${ }^{3}$ Instituto de Geociências, Universidade de São Paulo, Rua do Lago, 562, 05508-080 São Paulo, SP, Brazil \\ ${ }^{4}$ Dipartimento di Scienze della Terra “Ardito Desio", Università degli Studi di Milano, via Mangiagalli 34, \\ 20133 Milano, Italy \\ ${ }^{5}$ CrisDi, Interdepartmental Centre for Crystallography, via Pietro Giuria 5, 10125 Torino, Italy
}

\begin{abstract}
The newly defined gadolinite supergroup approved by the IMA CNMNC (vote 16-A) includes mineral species that have the general chemical formula $A_{2} M Q_{2} T_{2} \mathrm{O}_{8} \varphi_{2}$ and belong to silicates, phosphates and arsenates. Each site is occupied by: $A-\mathrm{Ca}, \mathrm{REE}$ (Y and lanthanoids), actinoids, $\mathrm{Pb}, \mathrm{Mn}^{2+}, \mathrm{Bi} ; M-\mathrm{Fe}, \square$ (vacancy), $\mathrm{Mg}, \mathrm{Mn}, \mathrm{Zn}, \mathrm{Cu}, \mathrm{Al} ; Q-\mathrm{B}, \mathrm{Be}, \mathrm{Li} ; T-\mathrm{Si}, \mathrm{P}, \mathrm{As}, \mathrm{B}, \mathrm{Be}, \mathrm{S} ;$ and $\varphi-$ $\mathrm{O}, \mathrm{OH}, \mathrm{F}$. The classification of the gadolinite supergroup is based on the occupancy of $A, M, Q, T$ and $\varphi$ sites and application of the dominant-valency and dominant-constituent rules. The gadolinite supergroup is divided into two groups defined by prevailing charge occupancy at the $T$ site $-\mathrm{Si}^{4+}$ in gadolinite group and $\mathrm{P}^{5+}$ or $\mathrm{As}^{5+}$ in herderite group. The gadolinite group is divided into the gadolinite and datolite subgroups. The $A$ site is dominantly occupied by divalent cations in the datolite subgroup and by trivalent cations in the gadolinite subgroup. Accordingly, the $Q$ site is dominantly occupied by $\mathrm{B}^{3+}$ in the datolite subgroup and by $\mathrm{Be}^{2+}$ in the gadolinite subgroup. The herderite group is divided into two subgroups. The herderite subgroup is defined by the dominant divalent cation (usually $\mathrm{Ca}^{2+}$ ) in the $A$ site and $\mathrm{Be}^{2+}$ in the $Q$ site, while the $M$ site is vacant. The drugmanite subgroup is defined by the dominance of divalent cations (usually $\mathrm{Pb}^{2+}$ ) in the $A$ site, vacancy in the $Q$ site and the occupation of the $M$ site. Moreover, "bakerite" is discredited as mineral species because it does not meet the conditions of the dominant-constituent rule.
\end{abstract}

Key-words: gadolinite supergroup; gadolinite; herderite; datolite; drugmanite; nomenclature.

\section{Introduction}

The newly defined gadolinite supergroup, approved by the Commission on New Minerals, Nomenclature and Classification (CNMNC) of the International Mineralogical Association (IMA) (vote 16-A), includes mineral species that have the general chemical formula $A_{2} M Q_{2} T_{2} \mathrm{O}_{8} \varphi_{2}$ and belong to silicates, phosphates and arsenates (Table 1). Each site is occupied by (the most common ions or vacancy are underlined):

$-A: \underline{\mathrm{Ca}}, \underline{\mathrm{REE}}(\underline{\mathrm{Y} \text { and lanthanoids }})$, actinoids, $\mathrm{Pb}, \mathrm{Mn}^{2+}, \mathrm{Bi}$; $-M: \overline{\mathrm{Fe}}, \bar{\square}$ (vacancy), $\mathrm{Mg}, \mathrm{Mn}, \mathrm{Zn}, \mathrm{Cu}, \mathrm{Al}$;

- Q: $\overline{\mathrm{B}}, \mathrm{Be}, \mathrm{Li}$

$-T: \overline{\mathrm{Si}}, \mathrm{P}, \mathrm{As}, \mathrm{B}, \mathrm{Be}, \mathrm{S}$;

$-\varphi: \underline{\overline{\mathrm{O}}}, \underline{\overline{\mathrm{O}}}, \mathrm{F}$.

All minerals of the gadolinite supergroup have monoclinic symmetry and are usually described in the two of three cell choices of the space group no. 14: choice $1, P 2_{1} / c(e . g$.
Foit et al., 1973) and choice 3, $P 2_{1} / a$ (e.g. Miyawaki et al., $1984,1985)$. For an internally consistent description of all members of the supergroup, we use here only $P 2_{1} / c$.

Historically, the use of the name and classification of the gadolinite supergroup has not been clearly defined; the "group" was referred to as "datolite group" as well as "gadolinite-datolite group", including or excluding nonsilicate members. Following the example of nomenclatures for the apatite (Pasero et al., 2010) and garnet (Grew et al., 2013) supergroups, which included silicate and nonsilicate members, the nomenclature of the gadolinite supergroup merges silicate minerals previously belonging to the "gadolinite-datolite group" and phosphates and arsenates with the gadolinite-type structure. Moreover, the need for three-level hierarchies requires the creation of a gadolinite supergroup instead of a gadolinite group.

In the past, there have also been invalid mineral species frequently included in the "datolite group". Later on, according to further research, they turned out to be transitional between end-member compositions. The list of these invalid species as well as other minerals mistakenly 
Table 1. Valid mineral species with gadolinite-type structure.

\begin{tabular}{|c|c|c|c|c|c|c|c|c|c|c|c|c|}
\hline & \multicolumn{6}{|c|}{ Crystal-chemical formula } & \multicolumn{5}{|c|}{ Lattice parameters } & Ref \\
\hline Datolite & $\mathrm{Ca}_{2}$ & $\square$ & $\mathrm{B}_{2}$ & $\mathrm{Si}_{2}$ & $\mathrm{O}_{8}$ & $(\mathrm{OH})_{2}$ & 4.832 & 7.608 & 9.636 & 90.40 & 354.2 & 1 \\
\hline Homilite & $\mathrm{Ca}_{2}$ & $\mathrm{Fe}^{2+}$ & $\mathrm{B}_{2}$ & $\mathrm{Si}_{2}$ & $\mathrm{O}_{8}$ & $\mathrm{O}_{2}$ & 4.776 & 7.621 & 9.786 & 90.61 & 356.2 & 2 \\
\hline Gadolinite-(Y) & $\mathrm{Y}_{2}$ & $\mathrm{Fe}^{2+}$ & $\mathrm{Be}_{2}$ & $\mathrm{Si}_{2}$ & $\mathrm{O}_{8}$ & $\mathrm{O}_{2}$ & 4.768 & 7.565 & 10.000 & 90.31 & 360.7 & 3 \\
\hline Gadolinite-(Ce) & $\mathrm{Ce}_{2}$ & $\mathrm{Fe}^{2+}$ & $\mathrm{Be}_{2}$ & $\mathrm{Si}_{2}$ & $\mathrm{O}_{8}$ & $\mathrm{O}_{2}$ & 4.820 & 7.580 & 10.010 & 90.28 & 347.1 & 4 \\
\hline Gadolinite-(Nd) & $\mathrm{Nd}_{2}$ & $\mathrm{Fe}^{2+}$ & $\mathrm{Be}_{2}$ & $\mathrm{Si}_{2}$ & $\mathrm{O}_{8}$ & $\mathrm{O}_{2}$ & 4.822 & 7.699 & 10.136 & 90.23 & 376.2 & 5 \\
\hline Hingganite-(Ce) & $\mathrm{Ce}_{2}$ & $\square$ & $\mathrm{Be}_{2}$ & $\mathrm{Si}_{2}$ & $\mathrm{O}_{8}$ & $(\mathrm{OH})_{2}$ & 4.751 & 7.628 & 9.897 & 90.42 & 358.6 & 7 \\
\hline Hingganite-(Yb) & $\mathrm{Yb}_{2}$ & $\square$ & $\mathrm{Be}_{2}$ & $\mathrm{Si}_{2}$ & $\mathrm{O}_{8}$ & $(\mathrm{OH})_{2}$ & 4.740 & 7.607 & 9.898 & 90.45 & 356.9 & 8 \\
\hline Minasgeraisite-(Y) & $\mathrm{Y}_{2}$ & $\mathrm{Ca}$ & $\mathrm{Be}_{2}$ & $\mathrm{Si}_{2}$ & $\mathrm{O}_{8}$ & $\mathrm{O}_{2}$ & 4.702 & 7.562 & 9.833 & 90.46 & 349.6 & 9 \\
\hline Herderite & $\mathrm{Ca}_{2}$ & $\square$ & $\mathrm{Be}_{2}$ & $\mathrm{P}_{2}$ & $\mathrm{O}_{8}$ & $\mathrm{~F}_{2}$ & 4.763 & 7.677 & 9.745 & 90.67 & 356.3 & 10 \\
\hline Hydroxylherderite & $\mathrm{Ca}_{2}$ & $\square$ & $\mathrm{Be}_{2}$ & $\mathrm{P}_{2}$ & $\mathrm{O}_{8}$ & $(\mathrm{OH})_{2}$ & 4.785 & 7.668 & 9.762 & 90.18 & 358.2 & 11 \\
\hline Drugmanite & $\mathrm{Pb}_{2}$ & $\mathrm{Fe}^{3+}$ & $\square$ & $\mathrm{P}_{2}$ & $\mathrm{O}_{7}(\mathrm{OH})$ & $(\mathrm{OH})_{2}$ & 4.643 & 7.986 & 11.111 & 90.41 & 358.2 & 12 \\
\hline
\end{tabular}

References: 1, Foit et al. (1973); 2, Miyawaki et al. (1985); 3, Miyawaki et al. (1984); 4, Segalstad \& Larsen (1978); 5, Škoda et al. (2016); 6, Demartin et al. (2001); 7, Miyawaki et al. (2007); 8, Demartin et al. (2001); 9, Foord et al. (1986); 10, Harlow \& Hawthorne (2008); 11, Harlow \& Hawthorne (2008); 12, King \& Sengier-Roberts (1988); 13, Hansen et al. (1984a).

Table 2. Invalid minerals and obsolete names formerly included in the gadolinite supergroup (in italic) and minerals shown not to belong to the gadolinite supergroup.

\begin{tabular}{lll}
\hline & Formula & Remark \\
\hline Calcybeborosilite-(Y) & $(\mathrm{Y}, \mathrm{Ca})_{2}\left(\square, \mathrm{Fe}^{2+}\right)(\mathrm{B}, \mathrm{Be})_{2} \mathrm{Si}_{2} \mathrm{O}_{8}(\mathrm{OH}, \mathrm{O})_{2}$ & 1 \\
Calciogadolinite-(Y) & $(\mathrm{YCa}) \mathrm{Fe}^{3+} \mathrm{Be}_{2} \mathrm{Si}_{2} \mathrm{O}_{8} \mathrm{O}_{2}$ & 2 \\
Yttroceberysite & $\mathrm{Y}_{2} \square \mathrm{Be}_{2} \mathrm{Si}_{2} \mathrm{O}_{8}(\mathrm{OH})_{2}$ & 3 \\
Xinganite & $\mathrm{Y}_{2} \square \mathrm{Be}_{2} \mathrm{Si}_{2} \mathrm{O}_{8}(\mathrm{OH})_{2}$ & 4 \\
Nd-dominant hingganite & $\mathrm{Nd}_{2} \square \mathrm{Be}_{2} \mathrm{Si}_{2} \mathrm{O}_{8}(\mathrm{OH})_{2}$ & 5 \\
Bakerite & $\mathrm{Ca}_{2} \square \mathrm{B}_{2} \mathrm{Si}_{1.5} \mathrm{~B}_{0.5}\left[\mathrm{O}_{7.5}(\mathrm{OH})_{0.5}\right](\mathrm{OH})_{2}$ & 6 \\
Euclase & $\mathrm{BeAlSiO}_{4}(\mathrm{OH})$ & 7 \\
Väyrynenite & $\mathrm{MnBePO}_{4}(\mathrm{OH})$ & 8 \\
\hline
\end{tabular}

Remarks: 1, name for mineral intermediate in composition between datolite and gadolinite published without approval of CNMNC IMA (Semenov et al., 1963; Povarennykh \& Dusmatov, 1970); 2, described by Nakai (1938) as ferrous and ferric yttrium calcium beryllium silicate and named according to composition and similarity with gadolinite, but considered questionable, discredited in 2006 as identical with Cabearing gadolinite (Burke, 2006). Ito (1967) reported a ferric yttrium calcium beryllium silicate, as the synthetic equivalent of "calciogadolinite". Ito \& Hafner (1974) proposed that (YCa) $\mathrm{Fe}^{3+} \mathrm{Be}_{2} \mathrm{Si}_{2} \mathrm{O}_{8} \mathrm{O}_{2}$ is one of the three end-members of a solid solution observed in natural gadolinite samples; 3, obsolete name of hingganite-(Y) (Ding et al., 1981); 4, the pinyin spelling of hingganite-(Y) name (Lulu \& ZhiZhong, 1986); 5, published composition of hingganite (Pršek et al., 2010) but not yet proposed as mineral species and approved by CNMNC IMA; 6, discredited; 7, first descriptions of the euclase structure indicated similarity to datolite structure but later structure refinement proved differences between both minerals (Biscoe \& Warren, 1930); 8, Volborth (1954) suggested the possibility that väyrynenite might be isostructural with herderite. However, structures of väyrynenite and herderite are entirely different as proved by later research $(e . g$. Mrose \& von Knorring, 1959).

included in the gadolinite supergroup is reported in Table 2, along with obsolete names of valid end-members. All of them except euclase and väyrynenite (which do not belong to the gadolinite supergroup) are therefore not valid and should be considered discredited from now on.

\section{Crystal chemistry of gadolinite-supergroup minerals}

The structure of gadolinite-supergroup (GSG) minerals can be described as a layered one composed of two different layers parallel to $\left(\begin{array}{lll}1 & 0 & 0\end{array}\right)$ and alternating along the
[ 1100 ] direction (in the $P 2_{1} / c$ space group). One layer consists of $T \mathrm{O}_{4}$ and $Q_{4}$ tetrahedra, and alternate with layers composed of both $A \mathrm{O}_{6} \varphi_{2}$ polyhedra and $M \mathrm{O}_{4} \varphi_{2}$ octahedra (Fig. 1).

\subsection{Tetrahedral sites}

Tetrahedral sites in the structure of GSG minerals are linked into regularly alternating 4 - and 8-membered rings (Fig. 2a) forming layers (Fig. 2b) (Miyawaki \& Nakai, 1996; Cámara et al., 2008). In the $P 2_{1} / c$ setting, all 8membered rings are stretched along $\mathbf{c}$, but rotated $25-30^{\circ}$ alternately clockwise and counterclockwise within the 

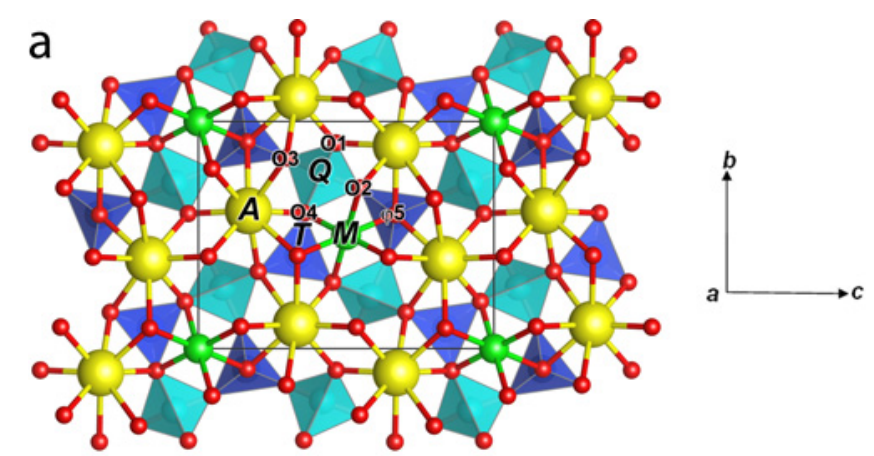

b

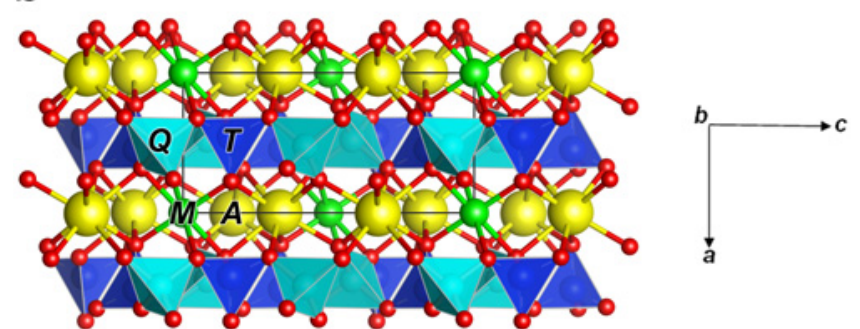

Fig. 1. The structure of gadolinite-supergroup minerals (structure of gadolinite-(Y) after Cámara et al., 2008): (a) view perpendicular to $\left(\begin{array}{lll}1 & 0 & 0\end{array}\right)$ and (b) view along $\left[\begin{array}{lll}0 & 1 & 0\end{array}\right]$ showing several alternating layers along [ $\left.\begin{array}{lll}1 & 0 & 0\end{array}\right]$. Graphics obtained with VESTA 3.1.6 (Momma \& Izumi, 2011).

(1 000$)$ plane (Bačík et al., 2014). The $T \mathrm{O}_{4}$ and $Q \mathrm{O}_{4}$ tetrahedra alternate regularly, every $T \mathrm{O}_{4}$ tetrahedron is connected to $3 Q_{4}$ tetrahedra and vice-versa.

The $T \mathrm{O}_{4}$ tetrahedron is occupied by $\mathrm{Si}, \mathrm{P}$ and $\mathrm{As}$ in silicates, phosphates and arsenates, respectively. Charge at the $T$ site can vary from $4^{+}$to $5^{+}$, although the observed partial substitution of B at the $T$ site in "bakeritic" datolite (Perchiazzi et al., 2006) implies that its charge can be as low as $3.5^{+}$. In silicates, significant substitution of $\mathrm{P}$ for $\mathrm{Si}$, up to 0.40 atom per formula unit (apfu) but usually below $0.05 a p f u$, was observed in GSG minerals from Gemerská Poloma, Bacúch, and Turčok, Slovakia (Uher et al., 2009; Pršek et al., 2010; Bačík et al., 2014), the Jaguaraçu Pegmatite, Minas Gerais, Brazil (Foord et al., 1986), and Skodefjellet, Svalbard (Majka et al., 2011). In contrast, bergslagite from Tennvatn pegmatite, Norway, contains 0.226 apfu Si replacing As and 0.06 apfu Si replacing Be (per $4 \mathrm{O}+1 \mathrm{OH}$ formula unit) (Raade et al., 2006). However, based on the current data, it is still unclear whether a continuous solid solution exists between silicates, phosphates and arsenates, or a miscibility gap.

The $Q \mathrm{O}_{4}$ tetrahedra are commonly occupied by B and/ or Be. Lithium can be also incorporated in GSG minerals and, if so, likely occurs in the $Q$ and $M$ sites owing to the exchange vectors: (1) ${ }^{M} \mathrm{Fe}^{2+}+{ }^{A} \mathrm{Y}^{3+} \rightarrow{ }^{M} \mathrm{Li}^{+}+{ }^{A}\left(\mathrm{Th}^{4+}+\right.$ $\mathrm{U}^{4+}$ ) and (2) ${ }^{Q} \mathrm{Be}^{2+}+{ }^{M} \mathrm{Fe}^{2+} \rightarrow{ }^{Q} \mathrm{Li}^{+}+{ }^{M} \mathrm{Fe}^{3+}$; the maximum amount of $\mathrm{Li}$ allowed in the gadolinite structure is 1.0 apfu (Cámara et al., 2008). Drugmanite is unique owing to the vacancy in the $Q$ site (King \& SengierRoberts, 1988). However, the population of other sites and the structure topology are similar to other GSG minerals,
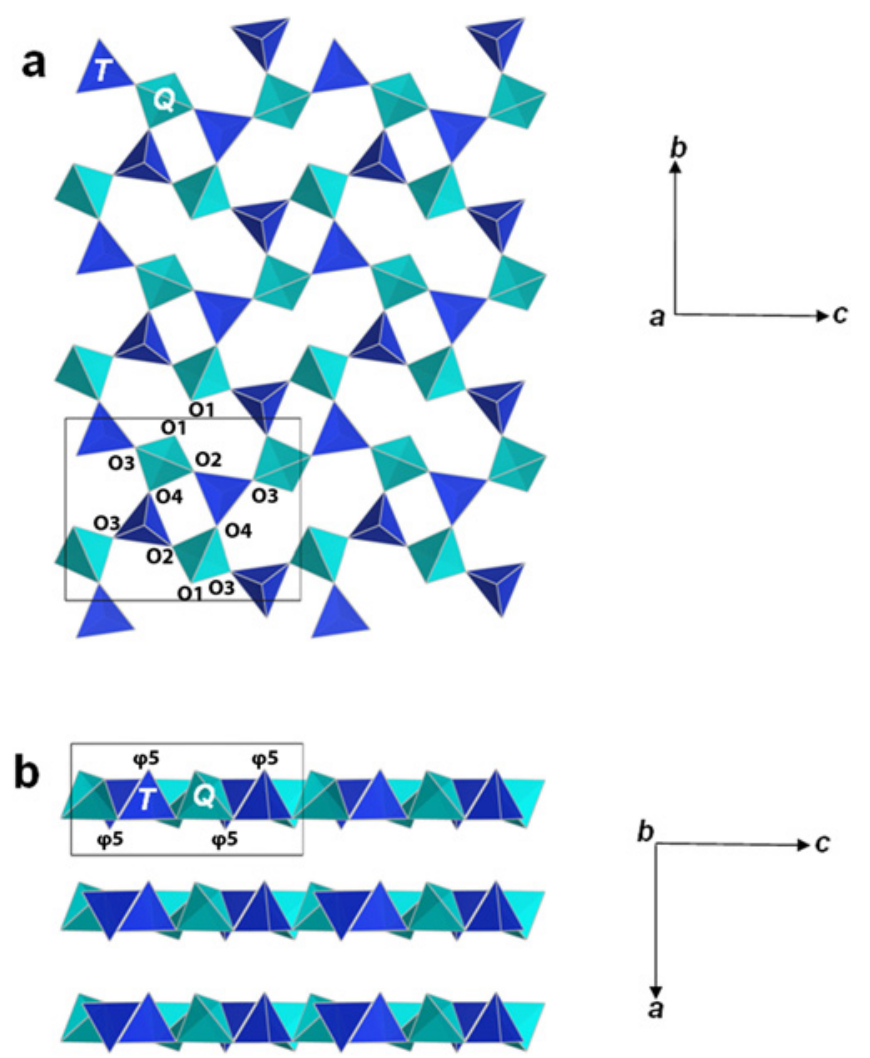

Fig. 2. Layers of $\mathrm{TO}_{4}$ (blue) and $\mathrm{QO}_{4}$ (turquoise) tetrahedra in the structure of GSG minerals (structure of gadolinite-(Y) after Cámara et al., 2008): (a) view perpendicular to (1 00 ) and (b) view along $\left[\begin{array}{lll}0 & 1 & 0\end{array}\right]$ showing alternance of several layers along [ 1000$]$. Graphics obtained with VESTA 3.1.6 (Momma \& Izumi, 2011).

and thus drugmanite belongs to the GSG. Although $\mathrm{H}$ atoms could not be located in its structure, one hydrogen position was tentatively proposed between two $\mathrm{O} 1$ sites (see location of $\mathrm{O} 1$ anions in Fig. 1), on the basis of the low bond-valence incidence calculated at these anion sites ( $c a$. 1.5 valence units (v.u.), King \& Sengier-Roberts, 1988). It seems therefore that the $Q$ sites are indeed vacant in the structure of drugmanite. Charge at the $Q$ sites can vary from 0 (vacant sites, drugmanite) to $3^{+}$(datolite).

\subsection{The $A$ site}

The $A$ site has the highest coordination number (8) in the structure of GSG minerals and forms distorted tetragonal antiprisms (Cámara et al., 2008). The higher coordination number allows the occupancy of the $A$ site by cations with ionic radii between $1.29(\mathrm{~Pb})$ and $0.977 \AA(\mathrm{Lu})$ (Shannon, 1976). However, $\mathrm{Ca}(1.12 \AA), \mathrm{Y}(1.019 \AA)$ and Ce (1.143 $\mathrm{\AA})$ are the most common cations occupying the $A$ site. Minor quantities of $\mathrm{Mn}(0.96 \AA)$ are found at the $A$ site. There is no evidence for the presence of monovalent cations at this site, although in principle there is no limitation in terms of local site dimensions and bond-valence requirements that would exclude the presence of, e.g., Na at the $A$ site. No remarkable deficiency has been reported for the $A$-site population, which 
a

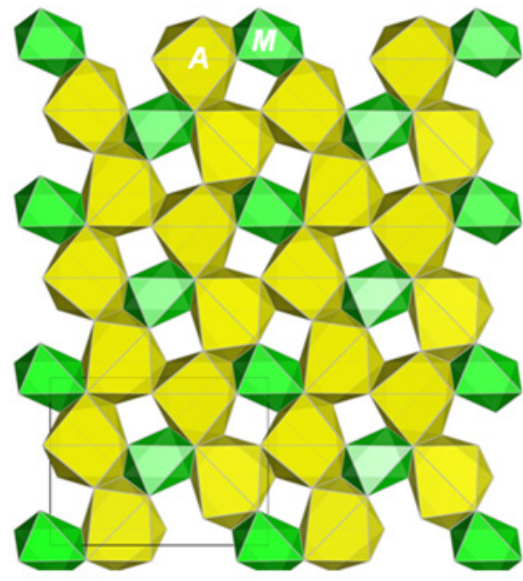

b
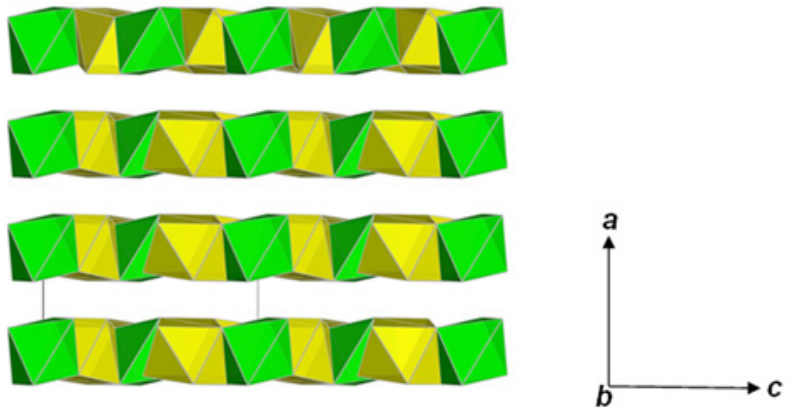

Fig. 3. Layers of $M \mathrm{O}_{4} \varphi_{2}$ octahedra (green) and $A \mathrm{O}_{6} \varphi_{2}$ (yellow) polyhedra in the structure of GSG minerals (structure of gadolinite(Y) after Cámara et al., 2008): (a) view along [ 1000$]$ and (b) view along [0 $\left.\begin{array}{ll}0 & 0\end{array}\right]$. Graphics obtained with VESTA 3.1.6 (Momma \& Izumi, 2011).

suggests the absence of an $A$-site-vacant end-member. Nevertheless, the charge at the $A$ site can vary considerably, from $2^{+}$to $3^{+}$.

The $A \mathrm{O}_{6} \varphi_{2}$ polyhedra are located in layers sandwiched between two tetrahedral layers (Fig. 3a) and also forms a network of irregular 6-membered rings, stretched at angles of $c a .20^{\circ}(+c$ and $-c)$ to the $\mathbf{b}$ direction. The rings enclose the $M$ site, which shares edges with the $A \mathrm{O}_{6} \varphi_{2}$ polyhedra (Fig. 3b). The $A \mathrm{O}_{6} \varphi_{2} M \mathrm{O}_{4} \varphi_{2}$ layer is bounded on both sides by 8-membered rings of tetrahedra (Bačík et al., 2014).

\subsection{The $M$ site}

The distorted $M \mathrm{O}_{4} \varphi_{2}$ octahedra are bounded on both sides of the $A \mathrm{O}_{6} \varphi_{2} M \mathrm{O}_{4} \varphi_{2}$ layer by 4-membered rings of $T$ and $Q$ tetrahedra. Each $M$-site cation is coordinated to pairs of $\mathrm{O} 2, \mathrm{O} 4$ and $\varphi 5$ anions. The $\mathrm{O} 2$ and $\mathrm{O} 4$ anions connect $T \mathrm{O}_{4}$ and $Q \mathrm{O}_{4}$ tetrahedra in neighbouring tetrahedral layers. The $\varphi 5$ anions, which are located at the $-a$ and $+a$ apices of $Q \mathrm{O}_{4}$ tetrahedra, are shifted out of $\left(\begin{array}{lll}0 & 0 & 1\end{array}\right)$. Thus, $M \mathrm{O}_{4} \varphi_{2}$ octahedra lie with an $\mathrm{O} 2 \mathrm{O} 4 \varphi 5$ face along $(001)$, with slight deflection of the corners with $\varphi 5$ anions. The $M$ site is located at the twofold symmetry axis in the corner of the unit cell. Consequently, $M$ sites in adjacent layers are located above one another, resulting in tunnels in the a direction (Bačík et al., 2014) when the $M$ sites are vacant, as in datolite or hingganite-(Y).
The $M$ site is commonly occupied by $\mathrm{Fe}^{2+}$ as in gadolinites (e.g. Miyawaki et al., 1984; Demartin et al., 2001; Cámara et al., 2008) and homilite (Miyawaki et al., 1985), although other divalent cations with ionic radius close to $\mathrm{Fe}^{2+}(\mathrm{Mg}, \mathrm{Mn}, \mathrm{Co}, \mathrm{Ni}, \mathrm{Cu}$ and $\mathrm{Zn}$ - Ito \& Hafner, 1974; Ni - Foit \& Gibbs, 1975) can also enter the site. Nevertheless, the $M$ site might also host large divalent cations like $\mathrm{Ca}$ in minasgeraisite-(Y), although the local strain requires relaxation and lowering of symmetry (Atencio, unpublished data).

The $M$ site might also be occupied by trivalent cations like $\mathrm{Fe}^{3+}$ as suggested by synthetic work (Ito, 1967). This was confirmed by Mössbauer spectroscopy on synthetic "calciogadolinite" (Ito \& Hafner, 1974). For the B-free solid-solution series in GSG, a coupled substitution $\mathrm{YFe}^{2+}\left(\mathrm{CaFe}^{3+}\right)_{-1}$ is required instead of $\mathrm{YBe}(\mathrm{CaB})_{-1}$ (Miyawaki \& Nakai, 1996). Ferric iron was suggested for a B-free (secondary ion microprobe analysis, SIMS, data) and Ca-rich (electron microprobe analysis, EMPA, data) GSG mineral from Tahara, Japan (Miyawaki et al., 1987) on the basis of $\mathrm{YFe}^{2+}\left(\mathrm{CaFe}^{3+}\right)_{-1}$. In contrast, Demartin et al. (1993) proposed, on the basis of observed $\langle M-\mathrm{O}\rangle$ distances, that iron is entirely in the divalent state in samples from the Alps. However, the incorporation of $\mathrm{Li}$ in the $Q \mathrm{O}_{4}$ tetrahedron implies that part of the iron might be in the trivalent state (Cámara et al., 2008). On the other hand, the $M$ site is commonly vacant as, e.g., in datolite and hingganite (e.g., Foit et al., 1973; Demartin et al., 2001; Miyawaki et al., 2007; Pršek et al., 2010; Majka et al., 2011); the charge is balanced by protonation of two oxygens at the $\varphi 5$ anion sites. Both protons are located inside the empty $M$ site due to steric hindrance requirements - to avoid repulsion with nearby cations. Therefore, the $M$ site is not actually vacant and the $\square(\mathrm{OH})_{2} \mathrm{Fe}_{-1} \mathrm{O}_{2}$ substitution can alternatively be expressed shortly as $\mathrm{H}_{2} \mathrm{Fe}_{-1}$. Charge at the $M$ site can vary from 0 (vacant site) to $3^{+}$.

\subsection{Anion sites}

There are five anion sites in general positions in the GSG minerals, which account for 10 anions per formula unit. The O2-4 sites are always occupied by oxygen, while $\mathrm{O} 1$ may be bonded to one $\mathrm{H}$ atom (as in drugmanite, King \& SengierRoberts, 1988). The $\varphi 5$ site hosts $\mathrm{O}$ atoms and can host $(\mathrm{OH})$ groups (as in datolite and hingganites) or F (as in herderite). The anion part of gadolinite supergroup (GSG) structure can account therefore for 16-20 negative charges.

\section{Definitions and classification principles}

The classification of the gadolinite supergroup (Table 3 ) is based on the occupancy of $A, M, Q, T$ and $\varphi$ sites and on the two rules used for classification of mineral species dominant-constituent rule and dominant-valency rule (Hatert \& Burke, 2008). The dominant-valency rule is used for occupancy of the $A$ and $M$ site, in which various trivalent and divalent cations (and vacancy in the $M$ site) occur, and 
Table 3. Approved gadolinite-supergroup nomenclature.

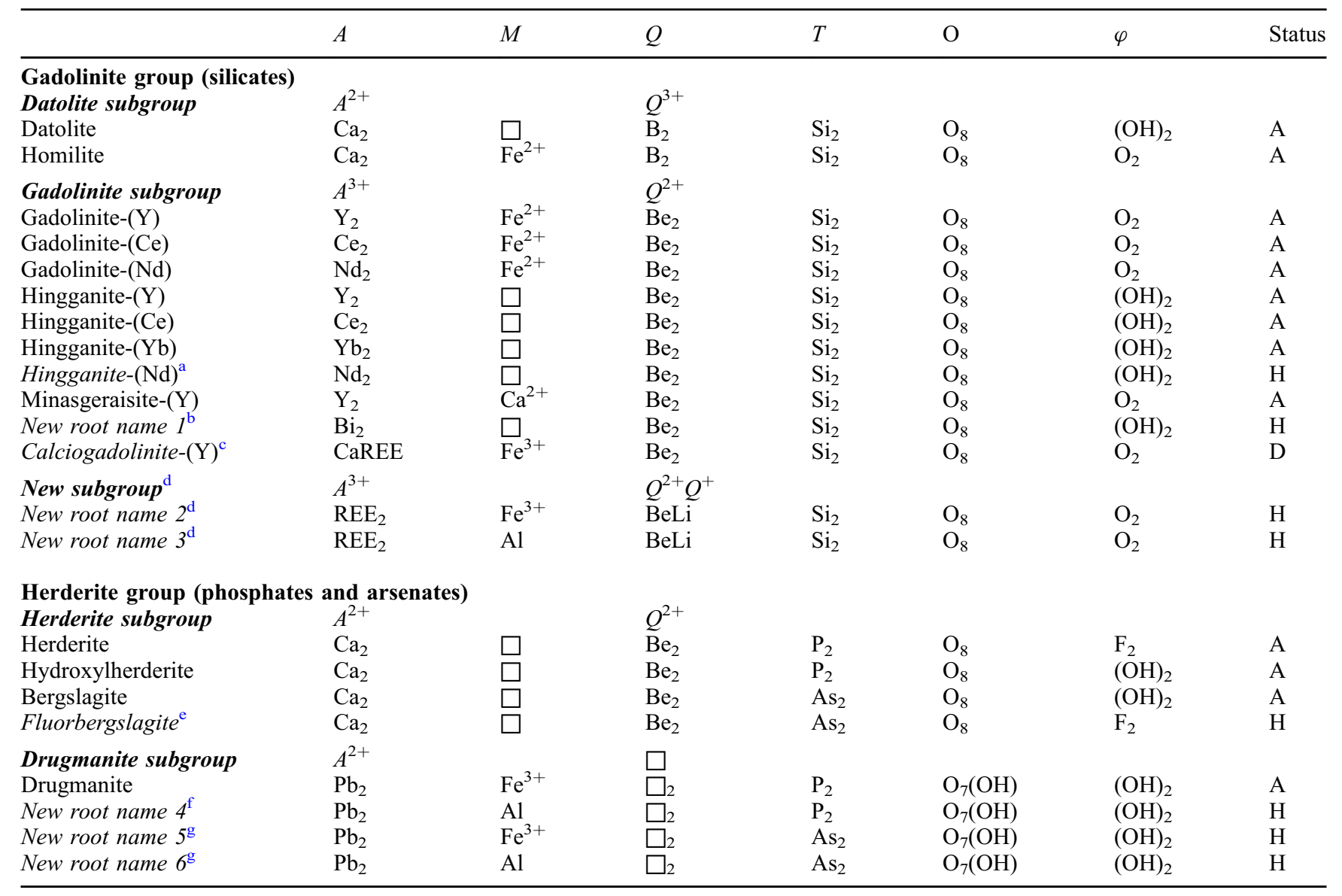

Status: A, approved; Rd, redefined; Rn, renamed; H, hypothetical end-members based on analytical data or real substitution trends; D, discredited, but hypothetical end-member based on analytical data or real substitution trends.

a Proposed end-member for Nd-dominant hingganite.

b Proposed Bi-dominant GSG mineral from Minas Gerais, Brazil described by Foord et al. (1986) as Bi-richest composition.

${ }^{c}$ Hypothetical end-member for the solid solution observed in natural gadolinite samples suggested by Ito \& Hafner (1974) and in natural hingganite samples suggested by Miyawaki et al. (1987) and Miyawaki \& Nakai (1996). The name of calciogadolinite-(Y) was used in published literature but use of a new root name is also possible.

d Proposed hypothetical subgroup and end-members with shared occupancy of $Q$ site by monovalent and divalent cation based on actual $\mathrm{LiFe}^{3+}\left(\mathrm{BeFe}^{2+}\right)_{-1}$ substitution described in gadolinite-(Y) from Vico, Italy (Cámara et al., 2008) and its Al dominant counterpart.

e Proposed F-dominant analogue of bergslagite.

${ }^{\mathrm{f}}$ Proposed end-member based on the actual Al-substitution for $\mathrm{Fe}^{3+}$ observed in natural drugmanite (Van Tassel et al., 1979).

g Arsenate analogue to drugmanite and "New root name 4" mineral.

also for the $T$ site, which can be occupied by various tetravalent and pentavalent cations (plus the so far never dominant $\mathrm{B}^{3+}$ ). The gadolinite supergroup is divided into two groups, which are consequently divided into several subgroups.

\subsection{Group}

Groups within the gadolinite supergroup were named according to the oldest members and are defined by prevailing occupancy at the $T$ site on the basis of the dominant-valence rule (Hatert \& Burke, 2008). Minerals with dominant $\mathrm{Si}^{4+}$ belong to the gadolinite group. Minerals with dominant pentavalent ions ( $\mathrm{P}$ and/or As) belong to the herderite group, also in the case that $\mathrm{Si}$ is the most abundant cation at the $T$ site but attains less than 1 apfu (Fig. 4).

\subsection{Subgroup}

The classification of a mineral into any of the subgroups is based on the dominant occupancy and valence in $A$ and $Q$ sites (Table 3). Difficulties in analyzing $B$ e and $B$ suggest that using occupancy of the $Q$ sites as a classification criterion is not advisable. Fortunately, determination of the occupation and the dominant charge of the $A$ site is usually adequate for assignment of a mineral to a subgroup. However, if the $Q$-site occupancy is not analytically determined and the occupation and the dominant charge of the $A$ site are not sufficient for determination of subgroup, the $M$-site occupancy can be used to assign a mineral to the proper subgroup.

In the gadolinite group there are two subgroups traditionally known - the gadolinite and datolite subgroups. The $A$ site is dominantly occupied by divalent 


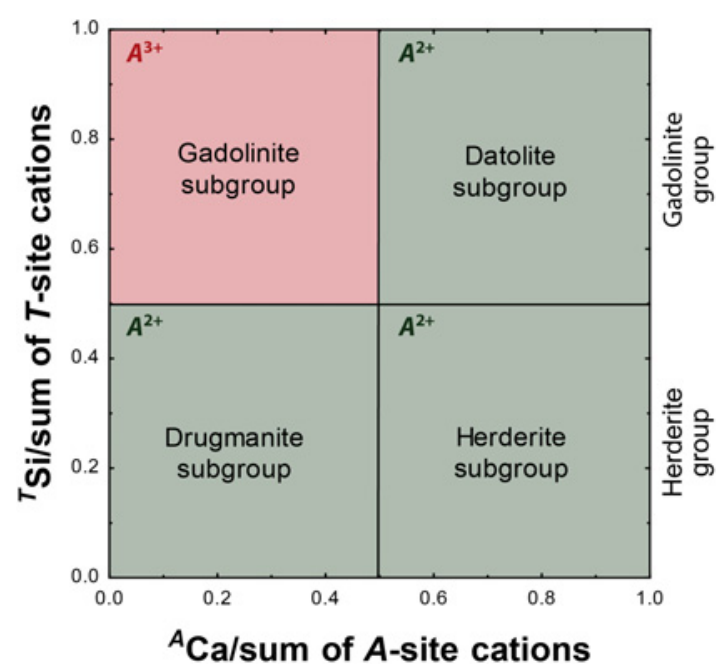

Fig. 4. Classification diagram of the gadolinite supergroup for determination of groups and subgroups. Inclusion of $A^{4+}$ dominant members would require an additional dimension in the diagram.

cations in the datolite subgroup and by trivalent cations in the gadolinite subgroup. Accordingly, the $Q$ site is dominantly occupied by $\mathrm{B}^{3+}$ in the datolite subgroup and by $\mathrm{Be}^{2+}$ in the gadolinite subgroup.

In the herderite group there are two subgroups: 1 - the herderite subgroup is defined by the dominance of divalent cations (usually $\mathrm{Ca}^{2+}$ ) in the $A$ site and $\mathrm{Be}^{2+}$ in the $Q$ site and 2 - the drugmanite subgroup is defined by the dominance of divalent cations (usually $\mathrm{Pb}^{2+}$ ) in the $A$ site and vacancy in the $Q$ site. Although divalent cations occupy the $A$ site in both subgroups, no solid solution between subgroups has been reported in natural samples. Therefore, determination of the $A$ site occupancy is in general satisfactory for specifying the subgroup (Fig. 4). However, if an intermediate composition is found and if it is impossible to distinguish $\mathrm{Be}$ or vacancy at the $Q$ site, the occupancy of the $M$ site can be used as additional criterion for establishing the proper subgroup in the herderite group.

Any new mineral with different occupancy of the $A$ and $Q$ sites compared to the above-listed subgroup occupancy (such as the "new root name 2" mineral with mixed occupancy of the $Q$ site by $\mathrm{Be}^{2+}$ and $\mathrm{Li}^{+}$in Table 2 , or a hypothetical mineral species with tetravalent cations at the $A$ site) will require the definition of a new subgroup.

\subsection{Root name, prefixes and suffixes}

The root name of GSG minerals is defined by the occupancy of the $A, M$ and $T$ sites.

- Occupancy of the $A$ site is expressed in two different ways: (1) if the dominant cation at the $A$ site in a new mineral is not a REE, it requires a new root name (e.g. datolite with dominant $\mathrm{Sr}$ should not be named datolite(Sr) or strontio-datolite but should have a different root name) and (2) if a new ${ }^{A}$ REE-dominant mineral differs from known species only in the dominant REE, the use of the Levinson-type suffix (Levinson, 1966) of the dominant REE added to the existing root name is recommended (e.g. Nd-dominant hingganite should be named hingganite-(Nd)). No other use of suffixes is recommended. This also applies to compositions otherwise similar to those of REE-dominant minerals, such as a Bi-dominant analogue of hingganite- $(\mathrm{Y})$ to which a new root name should be given. Hingganite(Bi) is not recommended.

- When the $M$ site is occupied (homilite, gadolinite, drugmanite), the dominant cation is usually $\mathrm{Fe}^{2+}$ (or $\mathrm{Fe}^{3+}$ in drugmanite), no other cation has been found so far to prevail in the $M$ site in GSG minerals. If the $M$ site occupancy is $>0.5 \mathrm{apfu}$ and $\mathrm{Fe}^{2+}$ (or $\mathrm{Fe}^{3+}$ in drugmanite) is not dominant, the use of a new root name is recommended.

- A change in the $T$-site population by heterovalent substitution results in changing the group; consequently, a new root name is necessary. The change in $T$-site population by homovalent substitution (e.g. substitution of As for $\mathrm{P}$ ) does not result in the change of group but the use of a new mineral root name is also recommended, instead of using a prefix. Consequently, the phosphate analogue of drugmanite, if any, should be given a new root name; the use of phosphodrugmanite is not recommended.

A prefix could be used to designate an occupant of the $\varphi 5$ site by a different anion than in an existing mineral of the supergroup. Currently such a prefix is used only in hydroxylherderite (see below). There is no need to use the prefix oxy- for ${ }^{\varphi} \mathrm{O}$ dominant datolite-group minerals as its presence causes the change in the $M$ site occupancy and subsequently results in a change of root name. Other uses of prefixes are not recommended.

\subsection{Adjectival modifiers}

Although a subordinate cation does not appear in the name of the GSG minerals, in some cases it may be of sufficient crystal-chemical or petrological interest to deserve mentioning, e.g., $0.70 \mathrm{Sr}$ apfu at the $A$ site. The International Mineralogical Association Commission on New Minerals and Mineral Names (predecessor of the IMA CNMNC) discredited the use of Schaller's modifiers, and recommended the use of expressions of the type $S r$ rich or Sr-bearing in such instance (voting proposal 03A; Bayliss et al., 2005). The use of such descriptors is discretional.

\subsection{Definition of mineral species}

As stated above, the dominant cations at the $A$ and $Q$ sites are decisive in the classification of a mineral into a subgroup within the gadolinite supergroup. As the population of the $Q$ site is not routinely determined by EMPA, it is appropriate to use only $A$ site population for classification of a mineral into a subgroup, whereas populations of the $A, M$ and $T$ sites are critical for defining 


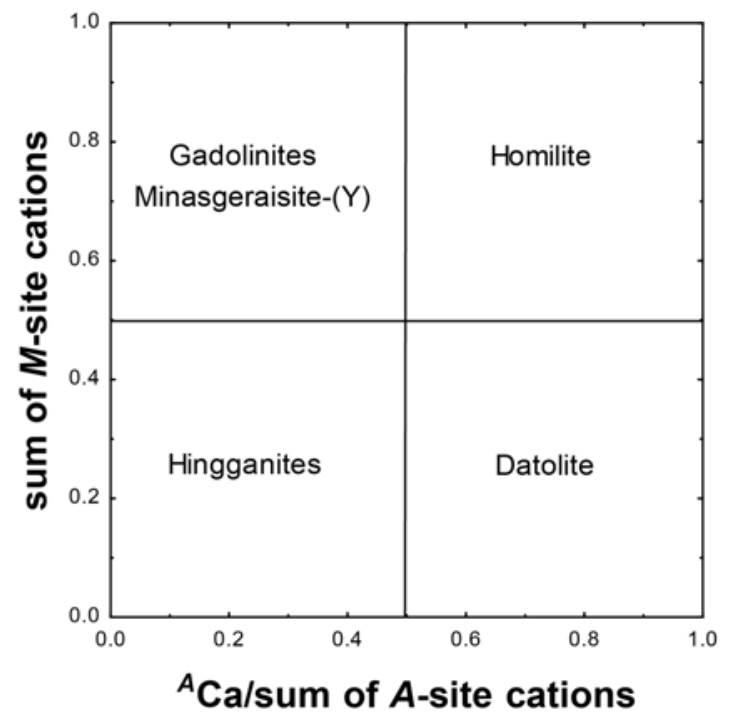

Fig. 5. Classification diagram of the gadolinite group for species determination.

the species. Similarly, the population of the $M$ and $A$ (if different from REE) sites is sufficient for determination of the root name. Moreover, in the case of homilite and bergslagite, occupancy of the $M$ and $A$ sites completely defines the end-member. In contrast, in the gadolinite subgroup it is necessary to determine the dominant trivalent cation in the $A$ site for classification into mineral species, thus only the root name is used in the classification diagram (Fig. 5).

Determination of $\mathrm{F}$ is necessary for classification of herderite and hydroxylherderite (Fig. 6). Drugmanite is the only GSG mineral with $\mathrm{Pb}$ in the $A$ site and no solid solution with other GSG mineral was observed; only $\mathrm{AlFe}^{3+}{ }_{-1}$ substitution (or $\mathrm{AlMn}^{3+}{ }_{-1}$ substitution) can produce new end-members of the gadolinite supergroup. Moreover, two As-dominant counterparts can be proposed (Fig. 7).

\section{Specific, invalid and discredited gadolinite- supergroup minerals}

Hereafter specific, invalid and discredited minerals of the gadolinite supergroup are discussed. We describe minerals with specific crystal-chemical features, minerals of which composition or other analytical data were published but that have not been proposed yet as new mineral species. Moreover, we explain the reasons for discrediting "bakerite".

\subsection{Minasgeraisite-(Y)}

Minasgeraisite-(Y) was originally described from the Jaguaraçu pegmatite, Minas Gerais, Brazil (Foord et al., 1986), which remains the only known locality. Only several hundred milligrams are known to exist. Its empirical formula was calculated from the ICP-AES data

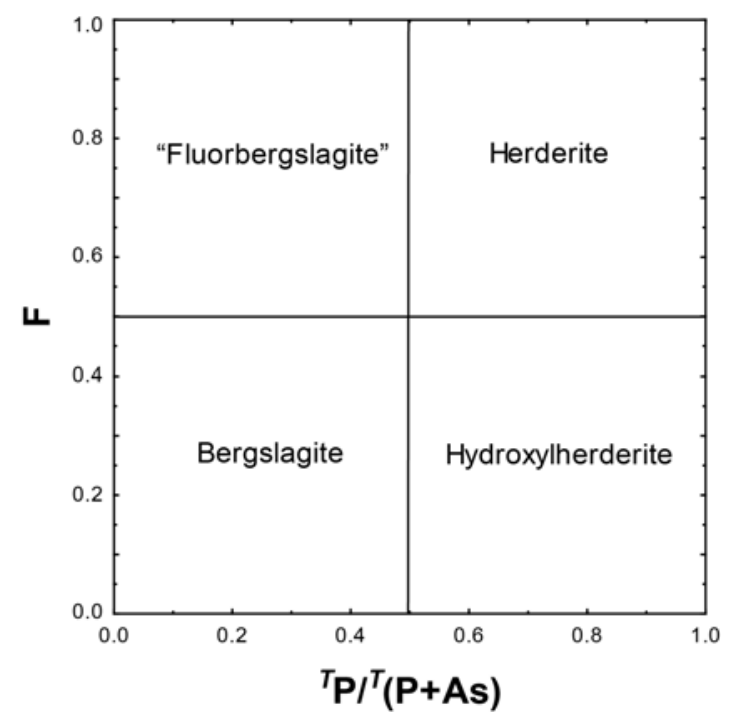

Fig. 6. Classification diagram of the herderite subgroup for species determination.

of bulk sample, namely an admixture of Bi-poor core and Bi-rich rim parts of the heterogeneous material, as $\left(\mathrm{Y}_{0.72} \mathrm{Ln}_{0.41} \mathrm{Ca}_{0.56} \mathrm{Bi}_{0.31}\right)_{\Sigma 2.00} \mathrm{Ca}_{0.45} \mathrm{Mn}_{0.20} \mathrm{Mg}_{0.08}$ $\left.\mathrm{Fe}_{0.05} \mathrm{Zn}_{0.02} \mathrm{Cu}_{0.01} \square_{0.19}\right)_{\Sigma 1.00}\left(\mathrm{Be}_{1.55} \mathrm{~B}_{0.21} \mathrm{Si}_{0.24}\right)_{\Sigma 2.00}\left(\mathrm{Si}_{1.95}\right.$ $\left.\mathrm{P}_{0.08}\right)_{\Sigma 2.03} \mathrm{O}_{10}$ on a $10 \mathrm{O}$ basis, where $\mathrm{Ln}$ is lanthanoids $(\mathrm{La}-\mathrm{Lu})$. As obvious from the formula, the excess in $\mathrm{Ca}$ content was assigned to the $M$ site. However, no structurerefinement data were obtained from type material to support the presence of $\mathrm{Ca}$ at the $M$ site. In contrast, there are arguments against it, which must be considered. Calcium has a large ionic radius ( $1.00 \AA$ in octahedral coordination Shannon, 1976) compared to other divalent cations, such as $\mathrm{Fe}^{2+}$. Calcium would lengthen the bonds in the octahedra to at least $2.38 \AA$, and the $<M-\varphi 5>$ distance would exceed by more than $0.3 \AA$ what has been observed in other structures that have been determined (Bačík et al., 2014). Moreover, the lattice parameters of minasgeraisite-( $(\mathrm{Y})$ are similar to those of hingganite-(Y), which suggests that neither the distortion in tetrahedral layers ( $b$ and $c$ ), nor the increase in layer distances $(a)$ owing the $\mathrm{CaFe}_{-1}$ substitution play a role in the minasgeraisite-(Y) structure (Bačík et al., 2014). The $(\mathrm{Na}, \mathrm{Mn}) \mathrm{O}_{6}$ octahedron in the structure of nordite-(La) (Bakakin et al., 1970) has an equivalent configuration to the $\mathrm{MO}_{4} \varphi_{2}$ octahedra in GSG minerals, between 4-membered $\mathrm{Si}_{4} \mathrm{O}_{12}$ rings of $\mathrm{SiO}_{4}$ tetrahedra. The mean $(\mathrm{Na}, \mathrm{Mn})-\mathrm{O}$ interatomic distance, $2.38 \AA$, suggests that the $M \mathrm{O}_{4} \varphi_{2}$ octahedron could accommodate the large $\mathrm{Ca}^{2+}$ cation. The interlayer distance of $5.16 \AA$ in nordite-(La) is greater than the interlayer distances in gadolinite and hingganite. Although the structure of the GSG minerals is sufficiently flexible to accommodate a wide range of ionic sizes between the layers, which is one of the reasons gadolinitesubgroup minerals crystallize as both smaller Y- and larger Ce-dominant members, there is no evidence in the cell parameters of minasgeraisite-( $(\mathrm{Y})$ for an increase of the interlayer distance. Therefore, it is unlikely that the $M$ site is dominantly occupied by $\mathrm{Ca}$. 


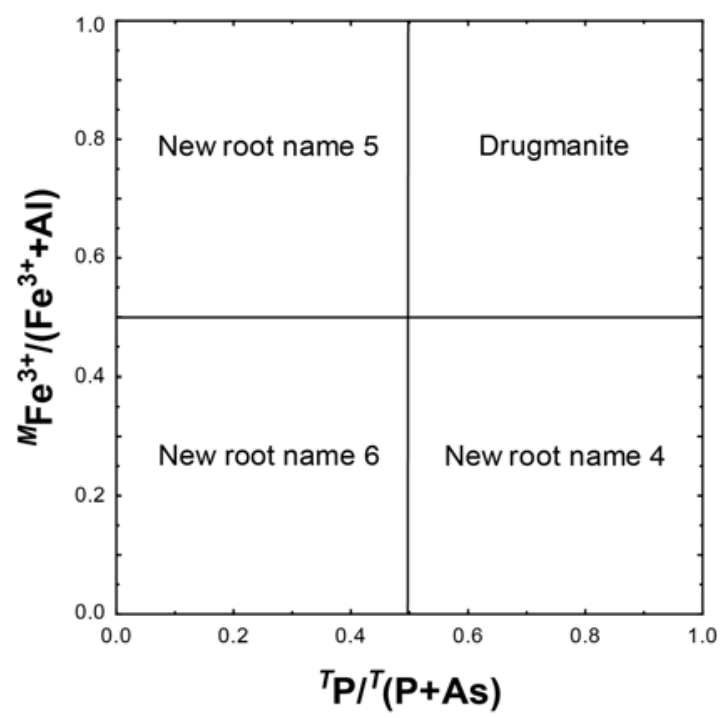

Fig. 7. Classification diagram of the drugmanite subgroup for species determination.

Moreover, calculation of minasgeraisite formula on the basis of 10 anions did not consider the possibility of $M$-site vacancy and $\mathrm{OH}$ groups, which results in the overestimation of calculated proportions of the other cations in the formula. Consequently, Ca content was overestimated and could not be accommodated at the $A$ site; the excess had to be placed at the $M$ site. Recalculation on the basis of $\mathrm{Si}+\mathrm{P}=2$ apfu (at the $T$ site) gave the formula: $\left(\mathrm{Y}_{0.64} \mathrm{Ln}_{0.36} \mathrm{Ca}_{0.72} \mathrm{Bi}_{0.28}\right)_{\Sigma 2.00}\left(\mathrm{Ca}_{0.18} \mathrm{Mn}_{0.18} \mathrm{Mg}_{0.07} \mathrm{Fe}_{0.04}\right.$ $\left.\mathrm{Zn}_{0.02} \mathrm{Cu}_{0.01} \square_{0.45}\right)_{\Sigma 1.00}\left(\mathrm{Be}_{1.80} \mathrm{~B}_{0.20}\right)_{\Sigma 2.00}\left(\mathrm{Si}_{1.92} \mathrm{P}_{0.08}\right)_{\Sigma 2.00}$ $\mathrm{O}_{8}\left(\mathrm{OH}_{1.38} \mathrm{O}_{0.62}\right)$. Following the dominant-valence and - constituent rules, the formula indicates that $M=\square$ and $\mathrm{Ca}=\mathrm{Mn}$ in the $M$ site. Therefore, the specimen of Foord et al. (1986) could be classified as Ca- and Bi-bearing hingganite-(Y) as well as Mn-bearing minasgeraisite-(Y).

Foord et al. (1986) reported the chemical data of the $\mathrm{Bi}$ richest portion. The recalculation of the Bi-richest composition on the basis of $2 T$ cations yielded the formula $\left(\mathrm{Bi}_{0.58} \mathrm{Y}_{0.47} \mathrm{Ln}_{0.29} \mathrm{Ca}_{0.68}\right)_{\Sigma 2.02}\left(\mathrm{Mn}_{0.23} \mathrm{Mg}_{0.07} \mathrm{Fe}_{0.05}\right.$ $\left.\mathrm{Zn}_{0.02} \mathrm{Cu}_{0.01} \square_{0.62}\right)_{\Sigma 1.00}\left(\mathrm{Be}_{1.48} \mathrm{~B}_{0.52}\right)_{\Sigma 2.00}\left(\mathrm{Si}_{1.92} \mathrm{P}_{0.08}\right)_{\Sigma 2.00}$ $\mathrm{O}_{8}\left(\mathrm{OH}_{1.25} \mathrm{O}_{0.75}\right)$, with the introduction of $\mathrm{OH}$ groups according to the procedure of formula calculation recommended for GSG minerals in the next section of this paper. Trivalent cations prevail in the $A$ site and $\mathrm{Bi}$ is the dominant cation among them, which, according to the dominant-valence rule, is sufficient for the definition of a new mineral species. The simplified formula, $\mathrm{Bi}_{2} \square \mathrm{Be}_{2} \mathrm{Si}_{2} \mathrm{O}_{8}(\mathrm{OH})_{2}$, conforms with the general formula of GSG minerals, $\mathrm{A}_{2} M Q_{2} T_{2} \mathrm{O}_{8} \varphi_{2}$.

Recently, the minasgeraisite-(Y) structure was solved and refined in space group $P 1$ by Cooper $\&$ Hawthorne (in preparation), using the chemical composition determined by Foord et al. (1986) on material from the same locality. Cooper \& Hawthorne (in preparation) found that lowering of the symmetry to acentric triclinic resulted from cation ordering at the $A$ site. In addition, they did not place any $\mathrm{Ca}$ at the $M$ site and refined the $M$-site occupancy using only the Mn scattering factor. Our nomenclature recommends that, if the occupancy of the $M$ site is $>0.5$ apfu and $\mathrm{Fe}^{2+}$ is not dominant, a new root name is to be used. However, the "valid" name "minasgeraisite-(Y)" is not applicable for the new root name of $\mathrm{Y}_{2} \mathrm{MnBe}_{2} \mathrm{Si}_{2} \mathrm{O}_{10}$.

Cooper \& Hawthorne (in preparation) gave the $M$-site composition $\left(\square_{1.37} \mathrm{Mn}_{0.63}\right)_{\Sigma 2}$, where both individual $M$ sites in their triclinic model have dominant vacancy. The structural formula (Y,Ca,Bi, Ln $)_{2}(\square, \mathrm{Mn})(\mathrm{Be}, \mathrm{B}$, $\mathrm{Si})_{2} \mathrm{Si}_{2} \mathrm{O}_{8}[(\mathrm{OH}), \mathrm{O}]_{2}$ on the basis of $\mathrm{O}+\varphi=10$ indicates that the mineral is $\left(\mathrm{Bi}^{3+}, \mathrm{Mn}^{2+}\right)$-bearing hingganite-( $\left.\mathrm{Y}\right)$. However, Cooper \& Hawthorne (in preparation) suggested that ordering at the $A$-site is a valid criterion for recognizing minasgeraisite-( $(\mathrm{Y})$ as a mineral species distinct from other GSG minerals, in all of which the $A$ site is disordered.

Foord et al. (1986) obtained powder X-ray diffraction data with a Gandolfi camera. However, the chemical composition of the crystal(s) on the camera is not mentioned. The sample was heterogeneous on a very fine scale $(<0.1 \mathrm{~mm})$. Foord et al. (1986) reported that rosettes of minasgeraisite are concentrically zoned with mediumpurple rims and pale-purple cores. The growth zoning was manifested by light and dark zones. Therefore, an admixture of minasgeraisite-(Y), the $\mathrm{Ca}$ - and $\mathrm{Bi}$ - bearing variety of hingganite-(Y) and the Bi-analogue of hingganite-(Y) (the new root name 1) was very likely present in the analyzed sample. The discrepancy in unitcell parameters between Foord et al. (1986) and Cooper \& Hawthorne (in preparation) suggests a difference in chemical composition between their crystals, although it could also partly result from the different methods used (Gandolfi camera vs. single-crystal structure refinement).

Although Cooper \& Hawthorne (in preparation) did not confirm the formula for minasgeraisite-(Y) proposed by Foord et al. (1986), their formula did retain many of the features of Foord et al. (1986) formula. Overall, questions concerning minasgeraisite-(Y) remain open, specifically the number of species present and the implications of ordering at the $A$ site. Any redefinition or new-mineral descriptions would require submission of a new proposal to the IMA CNMNC.

\subsection{Drugmanite}

Drugmanite was first described from Richelle, Belgium (Van Tassel et al., 1979). Electron microprobe data confirmed the presence of $\mathrm{Pb}, \mathrm{Fe}, \mathrm{Al}$ and $\mathrm{P}$, which could produce the possible formulae: $\mathrm{Pb}_{4.02}\left(\mathrm{Fe}^{3+}{ }_{1.55} \mathrm{Al}_{0.45}\right)$ $\mathrm{P}_{4.00} \mathrm{O}_{17.02} \cdot 3 \mathrm{H}_{2} \mathrm{O}$ or $\mathrm{Pb}_{2}\left(\mathrm{Fe}^{3+}{ }_{0.78} \mathrm{Al}_{0.22}\right)\left(\mathrm{PO}_{4}\right)_{2}(\mathrm{OH})$. $\mathrm{H}_{2} \mathrm{O}$. On the basis of powder diffraction pattern, the similarity to gadolinite, datolite-homilite and herderitehydroxylherderite series, namely GSG, was proposed (Van Tassel et al., 1979). Nothing was known about its structural arrangement until structure refinement, which revealed that drugmanite does indeed have a datolite-like structure (Fig. 8; King \& Sengier-Roberts, 1988). However, unlike the other GSG minerals, there is only one type of tetrahedra in the drugmanite structure, which is 

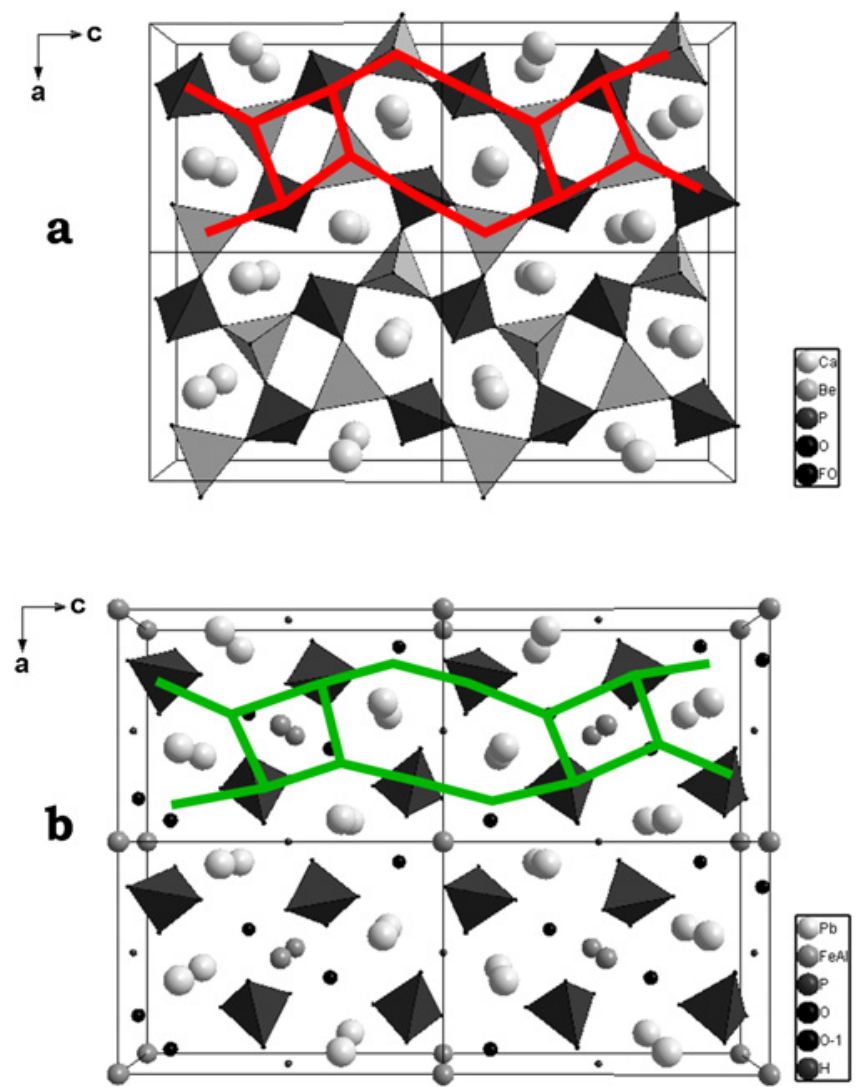

Fig. 8. Comparison of the (a) herderite (Harlow \& Hawthorne, 2008) and (b) drugmanite (King \& Sengier-Roberts, 1988) structure. Drugmanite contains only $\mathrm{TO}_{4}$ tetrahedra (dark grey) occupied by $\mathrm{P}$ and $Q_{4}$ tetrahedra are vacant, whereas herderite has both $\mathrm{TO}_{4}$ (dark grey) and $\mathrm{QO}_{4}$ (light grey) tetrahedra occupied by $\mathrm{P}$ and $\mathrm{Be}$, respectively. The red (in herderite) and green (in drugmanite) patterns highlight the structural motifs of 8 membered and 4-membered tetrahedral rings similar in both minerals.

occupied by $\mathrm{P}$. The $Q \mathrm{O}_{4}$ tetrahedron is vacant. The presence of vacancy in the $Q$ site requires definition of a drugmanite subgroup separately from the herderite subgroup, according to the nomenclature rules.

Similarly to "bakerite", the presence of molecular $\mathrm{H}_{2} \mathrm{O}$ proposed by Van Tassel et al. (1979) was not confirmed by King \& Sengier-Roberts (1988). However, the reason for the discrepancy between the $\mathrm{H}_{2} \mathrm{O}$ content estimated from microprobe data and later structural data in drugmanite and "bakerite" is different. In "bakerite" it was ascribed to impurities but bond-valence requirements indicate that drugmanite contains additional $\mathrm{OH}$ group. The additional hydrogen is probably bonded to $\mathrm{O} 1$ in $T \mathrm{O}_{4}$ tetrahedra, thus half of the $\mathrm{TO}_{4}$ tetrahedra is composed of $\mathrm{PO}_{4}$, the other half by $\mathrm{PO}_{3} \mathrm{OH}$ (King \& Sengier-Roberts, 1988). Moreover, King \& Sengier-Roberts (1988) were not able to locate $\mathrm{H}$ protons in their structure refinement. Only bond-valence calculations are providing evidence for insufficient charge at $\varphi 5$. However, the presence of cations in the $M$ site suggests that, if $\mathrm{H}$ is present at $\varphi 5$, it should be located differently than in other GSG minerals. It could be allowed by the vacancy in the $Q$ site. Conceivably, drugmanite could be an F-dominant mineral similar to herderite, but Van Tassel et al. (1979) did not mention F being detected in their preliminary qualitative analyses by optical spectrography and microchemical tests. Despite all differences, the structure of drugmanite is obviously similar to datolite (Fig. 8). Based on the structural data, the end-member formula of drugmanite was redefined to $\mathrm{Pb}_{2} \mathrm{Fe}^{3+}\left(\mathrm{PO}_{4}\right)\left(\mathrm{PO}_{3} \mathrm{OH}\right)(\mathrm{OH})_{2}$ (King \& Sengier-Roberts, 1988). For the present, this formula can be written as $\mathrm{Pb}_{2} \mathrm{Fe}^{3+} \square_{2} \mathrm{P}_{2}\left[\mathrm{O}_{7}(\mathrm{OH})\right](\mathrm{OH})_{2}$, which is consistent with the general formula of the GSG. However, it is still necessary to determine the exact $\varphi 5$ occupancy and $\mathrm{H}$ location in the structure.

Chemical analyses of drugmanite original material displayed a significant proportion of Al substituting for $\mathrm{Fe}^{3+}$ in the octahedral $M$ site (Van Tassel et al., 1979). The existence of an Al-dominant end-member in the drugmanite subgroup is therefore very likely. Moreover, two arsenates analogous to the herderite subgroup can be proposed (Table 3). Consequently, we prefer the definition of a subgroup with one valid end-member and one hypothetical end-member, instead of considering drugmanite as an unassigned member of the herderite group.

\subsection{Hingganite-(Nd)}

There is one valid Nd-dominant mineral species in the gadolinite group - gadolinite-(Nd), which was recently described as a new mineral from Malmkärra mine, WSW of Norberg, Sweden (with type specimen in the Moravian Museum, Czech Republic, catalogue number B 11298) and approved by the IMA-CNMNC (IMA No. 2016-013: Škoda et al., 2016). Similarly to gadolinite-(Nd), Nd-rich hingganite from Bacúch (Western Carpathians, Slovakia) displays $\mathrm{Nd}$ predominating over $\mathrm{Y}(\mathrm{Nd} / \mathrm{Y}=1.27-1.41)$ and other lanthanoids $(\mathrm{Nd} / \mathrm{Ce}=1.88-2.20 ; \mathrm{Nd} / \mathrm{Sm}=2.38-$ 2.67; $\mathrm{Nd} / \mathrm{Gd}=3.49-4.76$, and higher) (Pršek et al., 2010). The Nd content reaches $0.57 \mathrm{apfu} \mathrm{Nd}$, and concentrations of $\mathrm{Y}$ range from 0.40 to $0.49 \mathrm{apfu}$. In addition, $\mathrm{Nd}-$ dominant hingganite is generally Ca-poor $(\leq 0.01 \mathrm{apfu})$. Therefore, Nd-rich hingganite from Bacúch (Western Carpathians, Slovakia) corresponds to the new Nddominant member of the GSG - "hingganite-(Nd)". Nonetheless, it should be fully described and submitted to the CNMNC IMA for approval as a valid mineral species.

\section{4. "Bakerite" discredited}

"Bakerite" was first described by Giles (1903) with the chemical formula $\mathrm{Ca}_{8} \mathrm{~B}_{10} \mathrm{Si}_{6} \mathrm{O}_{30}(\mathrm{OH})_{10} \cdot \mathrm{H}_{2} \mathrm{O}$. According to Pemberton (1971), the true locality of Giles' material is Corkscrew Canyon, Death Valley, Inyo County, California. Palache et al. (1951) documented structural relationship between "bakerite" and datolite on powder X-ray diffraction patterns and proposed the chemical formula $\mathrm{Ca}_{8} \mathrm{~B}_{10} \mathrm{Si}_{6} \mathrm{O}_{30}(\mathrm{OH})_{10}$, recalculated on the basis of $40 \mathrm{O}$ and $\varphi$. Moreover, in the original formula of "bakerite", there was molecular $\mathrm{H}_{2} \mathrm{O}$ present (Giles, 1903), which should have been located near the $M$ site but was later 
ascribed to the presence of impurities and omitted from the formula $\mathrm{Ca}_{4} \square \mathrm{B}_{5} \mathrm{Si}_{3} \mathrm{O}_{15}(\mathrm{OH})_{5}$ (Perchiazzi et al., 2004). This formula can be written as $\mathrm{Ca}_{2} \square \mathrm{B}_{2}\left(\mathrm{Si}_{1.5} \mathrm{~B}_{0.5}\right)$ $\left[\mathrm{O}_{7.5}(\mathrm{OH})_{0.5}\right](\mathrm{OH})_{2}$, which is consistent with the general formula of GSG minerals.

"Bakerite" is therefore characterized by substitution of B for $\mathrm{Si}$ in the $T$ site, with a proposed charge-balance by $\mathrm{OH}$ placed in the $\mathrm{O} 1$ site. Hydrogen bonded to $\mathrm{O} 1$ has a different location compared to the $\mathrm{H}$ (at $H 5$ site) bonded to ${ }^{\varphi} \mathrm{O}$. It lies within the tetrahedral layer, whereas $\mathrm{H} 5$ is located on the edge of the tetrahedral layer. Hydrogen bonding between $\mathrm{H}$ and $\mathrm{O}$ at $\mathrm{O} 1$ of neighbouring $T \mathrm{O}_{4}$ octahedra could result in the structural arrangement with very well-ordered alternation of $\mathrm{B}$ and $\mathrm{Si}$ with the ratio of $5: 3$. As a result, there is supposedly a significant gap between the compositions of "bakerite" and datolite; there are no intermediate compositions between them (Perchiazzi et al., 2004).

However, it is not clear if this applies only to samples studied by Perchiazzi et al. (2004) or if it is a universal limit for $\mathrm{BSi}_{-1}$ substitution. In this case, the application of the dominant constituent rule (Hatert \& Burke, 2008) results in the discreditation of "bakerite". Boron occupies only $25 \%$ of the $T$ site, is therefore not dominant in this site and "bakerite" should not be treated as end-member. The only possibility to preserve "bakerite" as an end-member with respect to the dominant-constituent rule is the case of a highly ordered incorporation of B into one specific $T$ site, resulting in the splitting of $T$ into two sites with consequent reduction of structural symmetry. In this case B could occupy exactly $50 \%$ of the site, which would be consistent with the definition of the end-member. However, this was not fully proven by the structural study (Perchiazzi et al., 2004) and "bakerite", therefore, is discredited (IMA CNMNC 16-A).

\section{Calculation of the formula}

\subsection{Basis of formula calculation}

There are several possible procedures for calculation of chemical formula of GSG minerals. The calculation on the basis of 10 anions is proper only when all chemical data are available. In other cases, any calculation on the basis of anions is wrong in principle owing to the presence of $\mathrm{OH}$ groups, the possibility of variable amount of $\mathrm{Fe}^{3+}$, and the contents of $\mathrm{Be}, \mathrm{B}$ and $\mathrm{Li}$, which cannot be quantified by EMPA (or if they are - as in case of B - the precision of measurement is still unsatisfactory, see Ottolini et al., 2002). Therefore, if only EMPA data are available, calculation on the cation basis is a proper option. Calculation on the basis of 5 cations is inappropriate in principle owing to the presence of the $M$ site vacancy. Thus there remains three options of calculation - on the basis of (i) $4(A+T)$, (ii) $2 A$, and (iii) $2 T$ cations.

Calculation on the basis of $4(A+T)$ cations is not advisable owing to possible $\mathrm{CaFe}_{-1}$ and $\mathrm{BSi}_{-1}$ or $\mathrm{AlSi}_{-1}$ substitutions. We presume that $\mathrm{CaFe}_{-1}$ substitution is unlikely due to the structural properties of the $M \mathrm{O}_{4} \varphi_{2}$ octahedron, but the calculation on the basis of $2 T$ cations is a convenient test for this presumption. Moreover, it could take into account the possibility of $A$-site vacancy although, until now, there is no analytical evidence for it to be significant. In contrast the substitution of $\mathrm{B}$ or $\mathrm{Be}$ for $\mathrm{Si}$ at the $T$ sites could also generate certain nonstoichiometry if the formula is calculated on basis of 4 $(A+T)$ or $2 T$ cations. In this case, the calculation on the basis of $2 A$ cations yields the proper formula. Substitution of $\mathrm{Al}$ for $\mathrm{Si}$ is negligible in GSG minerals; Al likely fractionates at the $M$ site as documented by analyses of Albearing material. If no $\mathrm{BSi}_{-1}$ substitution is present, like in most GSG minerals, the recommended practice is to calculate formulae on the basis of $2 T$ and $2 A$ cations simultaneously and subsequently to choose the stoichiometrically more adequate formula, with a preference for the 2 T-cation calculation.

\subsection{The content of $\mathrm{O}, \mathrm{OH}$ and $\mathrm{F}$ in the $\varphi$ site}

The population in the $\varphi$ site depends directly on the occupancy of the $M$ site, as hydrogen cations are located in the vacant space of the $M \mathrm{O}_{4} \varphi_{2}$ octahedron. Fluorine content can be measured by EMPA. Provided that accuracy on F by means of EMPA is good enough, the $\mathrm{OH}$ content can be calculated as twice the $M$-site vacancy minus $\mathrm{F}$ and then the $\mathrm{O}$ content is equal to $2-(\mathrm{OH}+\mathrm{F})$. The presence of molecular $\mathrm{H}_{2} \mathrm{O}$, which was presumed to be located in the channels formed by vacant $M$ sites in "bakerite", was not confirmed by later research (Perchiazzi et al., 2004).

\subsection{Boron, beryllium and lithium}

Beryllium and lithium in the $Q$ site cannot be determined by EMPA; they should be calculated or determined by other methods. Special EMPA conditions are required for $B$ determination, such as using a layered dispersion element as monochromator for $\mathrm{B} K \alpha$ line with long $d$ spacing and accurate control of peak area and peak shape factors, as well as crystallographic orientation control (Bastin \& Heijligers, 1986a and b, 1991). Moreover, EMPA measurements of $\mathrm{B}$ require long counting times (e.g., $60 \mathrm{~s}$ on peak, $30 \mathrm{~s}$ on background) to improve statistics (McGee \& Anovitz, 1996). "Routine" operating conditions ( $10 \mathrm{kV}, 15 \mathrm{nA}$ beam current, $30 \mathrm{~s}$ counting time) yielded an approximate detection limit of $\sim 0.2-0.3 \mathrm{wt} \%$ $\mathrm{B}_{2} \mathrm{O}_{3}$ (McGee et al., 1991). However, the relative analytical error $(1 \sigma)$ of B measurement on EMPA is still relatively high, at the level of several percent (Kutzschbach et al., 2016). Nevertheless, structure refinement of many GSG minerals revealed occupancy of the $Q$ site by B along with Be (Demartin et al., 1993, 2001; Cámara et al., 2008). Thus, the sum of Be and B should be specifically mentioned in tabulations of EMPA data even if $\mathrm{B}$ and $\mathrm{Be}$ were not analyzed or calculated.

Moreover, lithium can be an important constituent of GSG minerals, and its presence should be systematically checked. Lithium should be suspected when (i) the 
$(\mathrm{Th}+\mathrm{U})$ content is significant or (ii) the sum $\mathrm{Si}+\mathrm{B}+\mathrm{Be}$ is lower than 2 apfu. Hence, metamict samples (containing $\mathrm{Th}$ and $\mathrm{U}$ ) could have significant Li contents (Cámara et al., 2008).

Provided that there is no $\mathrm{Li}$ in GSG minerals, the calculation of approximate B content may be done, if we assume that all $\mathrm{B}$ enters the structure through the $\mathrm{CaB}$ $(\mathrm{REE})_{-1} \mathrm{Be}_{-1}$ substitution, if $\mathrm{Fe}(\mathrm{Mn}, \mathrm{Mg}, \mathrm{Al})=0$ apfu . Subsequently, B would be proportional to the Ca content.

Another approach in $\mathrm{B} / \mathrm{Be}$ ratio calculation is based on the presumption that all $\mathrm{Fe}$ or $\mathrm{Mn}$ in the mineral is in divalent form and all ${ }^{\varphi} \mathrm{OH}$ serves to balance vacancy in the $M$ site. In this case, $\mathrm{Be}$ and $\mathrm{B}$ can be calculated from charge balance according to $\mathrm{Be}=6-[20-\Sigma \mathrm{PC}-\mathrm{OH}]$ (where $\Sigma \mathrm{PC}$ is the sum of charges for all cations except $\mathrm{B}$ and $\mathrm{Be}$ ) and $\mathrm{B}=2-\mathrm{Be}$. However, this procedure can be used only if data for all measurable cations are available and a correct calculation producing stoichiometrically more adequate formula is chosen.

Alternatively, if structural data are available, the $Q$ site population in terms of $\mathrm{Be}$ and $\mathrm{B}$ can be obtained using the calibration by Demartin et al. (2001) based on $\langle Q-\mathrm{O}\rangle$ distances, corrected by Cámara et al. (2008) for the possible presence of $\mathrm{Li}$.

Acknowledgements: We are indebted to Frédéric Hatert and all members of the IMA Commission on New Minerals, Nomenclature and Classification for their helpful suggestions and comments. We also thank Sergey V. Krivovichev for editorial handling and Edward Grew and Milan Novák for their detailed reviews.

\section{Appendix}

\section{Gadolinite-supergroup end-members: species, end-member formulae, etymology, type localities and eventual location of holotypes}

All known GSG minerals are monoclinic $P 2_{1} / c$. Representative chemical analyses are listed in Table S1, freely available online as Supplementary Material linked to this article on the GSW website of the journal: http://eurjmin. geoscienceworld.org.

\section{Datolite}

Structural formula: $\mathrm{Ca}_{2} \square \mathrm{B}_{2} \mathrm{Si}_{2} \mathrm{O}_{8}(\mathrm{OH})_{2}$.

IMA number: Grandfathered (1806).

Description: Datolite is the second described GSG mineral; Klaproth (1806) found it in Nødebro Mine, Norway. Its formation is commonly connected with volcanic or hydrothermal processes (Giles, 1903; Pemberton, 1971; Bellatreccia et al., 2006; Zaccarini et al., 2008). Datolite previously described as "bakerite" is also a microcrystalline material in various genetic environments, including diabase spilites (Baysal \& Dilekoz, 1975), diopside-bearing marble (Sabina, 1978), and gehlenitespurrite-bearing skarns (Kusachi et al., 1994). It is usually colorless or white, commonly with a greenish tinge; maybe grayish, yellow, green, red, pink. Datolite usually contains only insignificant proportion of other elements; the Fe substitution is limited up to $0.16 \mathrm{Fe} a p f u$, other elements are in even lower proportions (Grew, 1996, and references therein). Excess in $\mathrm{B}$ and its substitution for $\mathrm{Si}$ in the $T$ site is characteristic for "bakerite" (Perchiazzi et al., 2004).

Etymology: Named from the Greek, meaning to divide, in reference to the granular texture of the massive variety. Type locality: Nødebro Mine (Nøddebro), Arendal Iron Mines, Arendal, Aust-Agder, Norway.

Selected references: Klaproth (1806), Foit et al. (1973), Bellatreccia et al. (2006), and Rinaldi et al. (2010).

\section{Homilite}

Structural formula: $\mathrm{Ca}_{2} \mathrm{Fe}^{2+} \mathrm{B}_{2} \mathrm{Si}_{2} \mathrm{O}_{8} \mathrm{O}_{2}$.

IMA number: Grandfathered (1876).

Description: Homilite was first described by Paijkull (1876). Structure was solved by Miyawaki et al. (1985) on the material from type locality. The composition of the described homilite is near end-member with only up to 0.07 apfu ${ }^{\varphi} \square$ and 0.03 apfu Mn (Miyawaki et al., 1985). Homilite usually occurs in pegmatite bodies (Paijkull, 1876; Brögger, 1890). It was also discovered in a volcanic ejectum at Tre Croci, Vico volcanic complex, Viterbo Province, Latium, Italy (Pierini, 2004; Boiocchi et al., 2006). A possible third locality was reported in Romania (Hîrtopanu et al., 2003).

Etymology: Name from the Greek meaning to occur together, in allusion to its association with meliphanite and allanite.

Type locality: Stokø Island, Langesundfjord, Norway. Location of holotype: Muséum National d'Histoire Naturelle, Galerie Nationale de Minéralogie et de Géologie, Paris, France (catalogue \# 78142), Naturhistoriske Riksmuseet, Sektionen för Mineralogi, Stockholm, Sweden (catalogue \# 531010).

Selected references: Paijkull (1876) and Miyawaki et al. (1985).

\section{Gadolinite-(Y)}

Structural formula: $\mathrm{Y}_{2} \mathrm{Fe}^{2+} \mathrm{Be}_{2} \mathrm{Si}_{2} \mathrm{O}_{8} \mathrm{O}_{2}$.

IMA status: Renamed (1987).

Description: Gadolinite-(Y) has been an important mineral in the history of the discovery of rare-earth elements since yttria was first separated by J. Gadolin in 1794. The structure of gadolinite-(Y) was derived from datolite structure by simple replacement of atoms (Ito \& Mori, 1953). Afterwards, the structure was refined by Miyawaki et al. (1984). Gadolinite-(Y) forms accessory phases in REE- and Be-rich granites and pegmatites, and also in some metamorphic rocks (Demartin et al., 1993; Holtstam \& Andersson, 2007). Recent classification of rare-element granitic pegmatites (Černý, 1991; Černý \& Ercit, 2005) includes the gadolinite NYF (Nb-Y-F) sub-type family with typical mineralogical association consisting of gadolinite, fergusonite, euxenite, topaz and beryl. Most enriched in $\mathrm{Ca}$ (up to $0.84 \mathrm{apfu}$ ) is gadolinite-(Y) from Baveno, Italy (Pezzotta et al., 1999), Skodefjellet, 
Svalbard (Majka et al., 2011), and Dlhá Dolina, Slovakia (Bačík et al., 2014). The highest contents of $\mathrm{Mg}$ in gadolinite-(Y) (up to 0.048 apfu) were found in Kola Peninsula, Russia (Voloshin et al., 2002), Michalowice, Poland (Kozłowski \& Dzieržanowski, 2007) and Mn (up to $0.048 \mathrm{apfu}$ ) in Skodefjellet, Svalbard (Majka et al., 2011), Michalowice, Poland (Kozłowski \& Dzieržanowski, 2007). Aluminium-rich gadolinite (up to $0.19 \mathrm{apfu}$ ) occurs in Kola Peninsula, Russia (Voloshin et al., 2002), Rode Ranch, Texas, USA (Gibson \& Ehlmann, 1970). Gadolinites-(Y) specially enriched in lanthanoids are from Dlhá Dolina, Slovakia - Dy 0.152 apfu, Er 0.079 apfu (Bačík et al., 2014), Baveno, Italy - Nd 0.271 apfu, Gd 0.147 apfu, Dy 0.108 apfu (Pezzotta et al., 1999), and Turčok, and Slovakia - Nd 0.165 apfu, Dy 0.144 apfu, Er 0.089 apfu (Uher et al., 2009; Bačík et al., 2014).

Etymology: Named after the Finnish chemist Johan Gadolin (1760-1852), who discovered yttrium.

Type locality: Ytterby, Sweden.

Modifications of end-member definition: Renamed after CNMNC IMA approval owing to description of gadolinite-(Ce).

Selected references: Klaproth (1802) and Miyawaki et al. (1984).

\section{Gadolinite-(Ce)}

Structural formula: $\mathrm{Ce}_{2} \mathrm{Fe}^{2+} \mathrm{Be}_{2} \mathrm{Si}_{2} \mathrm{O}_{8} \mathrm{O}_{2}$.

IMA number: 1987 s.p.

Description: Gadolinite-(Ce) is similar to gadolinite-(Y), but is lanthanoid-dominant with most abundant $\mathrm{Ce}$ (Segalstad \& Larsen, 1978). It is commonly rich in $\mathrm{Mg}$ (up to $0.191 a p f u$ and Mn (up to 0.148 apfu) in several localities in Sweden (Holtstam \& Andersson, 2007). Variable Y content (up to $0.821 a p f u$ ) is observable in Baveno, Italy, gadolinite (Pezzotta et al., 1999). Calciumrich gadolinites were found in Cuasso al Monte, Italy (up to 0.263 apfu) (Pezzotta et al., 1999) and Skien in Norway (up to 0.283 apfu) (Segalstad \& Larsen, 1978).

Etymology: Named for its cerium content and the relationship to gadolinite-(Y).

Type locality: Bjørkendalen region, and in the Bakken quarry, Tvedalen, Norway.

Location of holotype: Mineralogical-Geological Museum, University of Oslo, Oslo, Norway (catalogue \# 21325).

Selected reference: Segalstad \& Larsen (1978).

\section{Gadolinite-(Nd)}

\section{Structural formula: $\mathrm{Nd}_{2} \mathrm{Fe}^{2+} \mathrm{Be}_{2} \mathrm{Si}_{2} \mathrm{O}_{8} \mathrm{O}_{2}$.}

IMA number: 2016-013.

Description: Gadolinite-(Nd) is similar to gadolinite-(Y), but is lanthanoid-dominant with most abundant $\mathrm{Nd}$ (Škoda et al., 1978).

Etymology: Named for its neodymium content and the relationship to gadolinite-(Y).

Type locality: Malmkärra mine, ca. $2.5 \mathrm{~km}$ WSW of Norberg, Sweden.

Location of holotype: Moravian Museum, Brno, Czech Republic (catalogue \# B 11298).

Selected reference: Škoda et al. (2016).

\section{Hingganite-(Y)}

Structural formula: $\mathrm{Y}_{2} \square \mathrm{Be}_{2} \mathrm{Si}_{2} \mathrm{O}_{8}(\mathrm{OH})_{2}$.

IMA number: Renamed (1981-052).

Description: Hingganite-( $\mathrm{Y})$ is the hydrous, Fe-free analogue of gadolinite-(Y). The most Fe-rich hingganite-(Y) is from Cuasso al Monte, Italy (up to $0.496 \mathrm{apfu}$ ) (Demartin et al., 1993). The most Ca-rich hingganite-(Y) (up to $0.961 a p f u$ ) is from Dara-i-Pioz Glacier, Tajikistan (Pekov et al., 2000), then from Vico lake, Italy (Cámara et al., 2008), Vlastějovice, Czech Republic (Bačík et al., 2014), Skodefjellet, Svalbard (Majka et al., 2011), Turčok, Slovakia (Uher et al., 2009), Gemerská Poloma, Slovakia (Bačík et al., 2014), Mont Blanc, France (Demartin et al., 1993), and Strange Lake, Canada (Jambor et al., 1998). Specimens rich in Mn (up to $0.101 \mathrm{apfu}$ ) are from Vlastějovice, Czech Republic (Bačík et al., 2014) and Skodefjellet, Svalbard (Majka et al., 2011). The specimens from Ploskaya Mt, Keivy Mountains, Kola Peninsula, Russia (Voloshin et al., 2002) are rich in lanthanoids - Yb (up to 0.393 apfu), Dy (up to $0.223 a p f u$ ), and Er (up to $0.229 a p f u$ ).

Etymology: Named after its type locality.

Type locality: Heilonghiang, and greater Xingan (Hinggan) area, Manchuria, China.

Location of holotype: National Museum for Geology, Beijing, China.

Modifications of end-member definition: Renamed after description of hingganite-( $\mathrm{Yb})$.

Selected references: Ding et al. (1984) and Demartin et al. (2001).

\section{Hingganite-(Ce)}

Structural formula: $\mathrm{Ce}_{2} \square \mathrm{Be}_{2} \mathrm{Si}_{2} \mathrm{O}_{8}(\mathrm{OH})_{2}$.

IMA number: 2004-004.

Description: Hingganite-(Ce) is the $\mathrm{Ce}$ analogue of hingganite-(Y) (Ding et al., 1984), and can be also expressed as the hydrated Fe-free analogue of gadolinite(Ce) (Segalstad \& Larsen, 1978). Hingganite-(Ce) richest in Fe (up to 0.486 apfu) is from Bacúch, Slovakia (Pršek et al., 2010) and Strange Lake, Canada (Jambor et al., 1998); in Y (up to 0.936 apfu) from Bacúch, Slovakia (Pršek et al., 2010); in Mn (up to 0.024apfu) from Strange Lake, Canada (Jambor et al., 1998). Hingganites(Ce) significantly enriched in lanthanoids are from Bacúch, Slovakia with Ce 0.353 apfu, Gd 0.149apfu and in some compositions with $\mathrm{Nd}$ up to $0.566 \mathrm{apfu}$ which corresponds to hingganite-(Nd) composition (Pršek et al., 2010), and from Tahara, Japan - Ce 0.814apfu, La 0.322 apfu (Miyawaki et al., 2007).

Etymology: Named for its relationship to hingganite-(Y). Type locality: Tahara, Nakatsugawa, Gifu Prefecture, Japan.

Location of holotype: National Museum of Nature and Science, Japan (catalogue \# NSM-M28552).

Selected reference: Miyawaki et al. (2007).

\section{Hingganite-(Yb)}

Structural formula: $\mathrm{Yb}_{2} \square \mathrm{Be}_{2} \mathrm{Si}_{2} \mathrm{O}_{8}(\mathrm{OH})_{2}$.

IMA number: 1982-041. 
Description: Hingganite- $(\mathrm{Yb})$ is the $\mathrm{Yb}$ analogue of hingganite-( $\mathrm{Y})$. The best known hingganite-( $\mathrm{Yb})$ is from Ploskaya Mt, Keivy Mountains, Kola Peninsula, Russia. It is characterized by extremely low amount of $\mathrm{Fe}$ (up to $0.006 \mathrm{apfu}$ ) and conversely high amounts of lanthanoids and $\mathrm{Y}$, especially $\mathrm{Yb}$ (up to $0.940 a p f u$ ) and $\mathrm{Y}$ (up to 0.832 apfu) (Voloshin et al., 2002).

Etymology: Named for its relationship to hingganite-(Y). Type locality: Mt. Ploskaya, Keivy massif, Kola Peninsula, Russia.

Location of holotype: Fersman Mineralogical Museum, Moscow, Russia (catalogue \# 84278-80), Institute of Geology, Kola Science Center of the Russian Academy of Sciences, Apatity, Russia (catalogue \# 5768), and Mining Museum, St.Petersburg, Russia (catalogue \# 1590/1).

Selected references: Voloshin et al. (1983) and Yakubovich et al. (1983).

\section{Minasgeraisite-(Y)}

Structural formula: $\mathrm{Y}_{2} \mathrm{CaBe}_{2} \mathrm{Si}_{2} \mathrm{O}_{8} \mathrm{O}_{2}$.

IMA number: 1983-090.

Description: Minasgeraisite is solely known from the type locality and contains major Y $(0.72 a p f u)$ and lanthanoids (sum of 0.41 apfu), Bi (0.31 apfu), Ca (0.56 apfu in $A$ site and 0.45 apfu in $M$ site, see discussion in text) and Mn (up to $0.20 a p f u)$ and very low $\mathrm{Fe}(0.05 a p f u)$. It occurs as a sparse, accessory, late-stage mineral in small druses in a zoned, complex granitic pegmatite. Minasgeraisite coats and is intergrown with milarite, muscovite, quartz, albite (Foord et al., 1986).

Etymology: Named after its locality.

Type locality: The Jaguaraçu Pegmatite, Minas Gerais, Brazil, also known as the Jose Miranda mine or the Zé Pinto or José Pinto mine.

Location of holotype: U.S. National Museum, Washington, USA (catalogue \# 164209).

Selected reference: Foord et al. (1986).

\section{Herderite}

Structural formula: $\mathrm{Ca}_{2} \square \mathrm{Be}_{2} \mathrm{P}_{2} \mathrm{O}_{8} \mathrm{~F}_{2}$.

IMA number: Grandfathered (1828).

Description: Herderite is ideally the F end-member in a solid-solution series with hydroxyl-herderite and occurs in complex granite pegmatite (Harlow \& Hawthorne, 2008). Herderite from Mogok Myanmar is rich in F (0.748 apfu) and $\mathrm{Na}(0.015 a p f u)$. Sodium is the main additional constituent in the Mogok sample (Harlow \& Hawthorne, 2008).

Etymology: Named for Siegmund August Wolfgang von Herder (1776-1838), mining official in Freiberg, Saxony, Germany.

Type locality: Ehrenfriedersdorf, Saxony, Germany.

Location of holotype: Werner-Sammlung der Bergakademie Freiberg (Massanek et al., 1999) and may be considered a topotype (Embrey \& Hey, 1970).

End-member definition: The F-dominant member in the herderite subgroup.

Selected references: Haidinger (1828) and Harlow \& Hawthorne (2008).

\section{Hydroxylherderite}

Structural formula: $\mathrm{Ca}_{2} \square \mathrm{Be}_{2} \mathrm{P}_{2} \mathrm{O}_{8}(\mathrm{OH})_{2}$.

IMA number: Renamed (2007) s.p.

Description: Hydroxyl-herderite occurs in granite pegmatites, greisens, and miarolitic cavities associated with granites and granitic pegmatites (Černý, 2002; Grew, 2002). Hydroxylherderite from Ehrenfriedersdorf Germany has almost equal contents of $\mathrm{F}(0.483 \mathrm{apfu})$ and $\mathrm{OH}$ (0.517 apfu) (Harlow \& Hawthorne, 2008) but hydroxylherderite from Manitoba Canada is much closer to end-member, with up to $0.996 \mathrm{OH} a p f u$, low amount of $\mathrm{Cl}$ (up to $0.004 a p f u$ ), F (up to $0.007 a p f u$ ) and some $\mathrm{Na}$ (up to 0.021 apfu) (Černá et al., 2002).

Etymology: Named for the composition and relationship to herderite.

Type locality: Paris, Maine, USA.

End-member definition: The $(\mathrm{OH})$-dominant member in the herderite subgroup.

Selected references: Penfield (1894), Černá et al. (2002), and Harlow \& Hawthorne (2008).

\section{Drugmanite}

Structural formula: $\mathrm{Pb}_{2} \mathrm{Fe}^{3+} \square \mathrm{P}_{2}\left[\mathrm{O}_{7}(\mathrm{OH})\right](\mathrm{OH})_{2}$. IMA number: 1978-081.

Description: Drugmanite is a very rare mineral, formed at low temperatures in vugs in mineralized limestones, an oxidation product of disseminated sulfides. It contains up to $0.223 \mathrm{Al}$ apfu (Van Tassel et al., 1979). It was found at the type locality Richelle, Belgium (Van Tassel et al., 1979) and Neue Hoffnung Mine, Eifel, Germany (Schnorrer \& Schäfer, 1999).

Etymology: Named for Julien Drugman (1875-1950), Belgian mineralogist.

Type locality: Richelle, near Visé, Belgium.

Location of holotype: Belgian Royal Institute of Natural Sciences, Brussels, RN5210; University of Liège, Liège, Belgium, 19347.

Selected references: Van Tassel et al. (1979) and King \& Sengier-Roberts (1988).

\section{Bergslagite}

Structural formula: $\mathrm{Ca}_{2} \square \mathrm{Be}_{2} \mathrm{As}_{2} \mathrm{O}_{8}(\mathrm{OH})_{2}$.

IMA number: 1983-021.

Description: Bergslagite occurs in thin veins in pieces of hematite ore found on mine dumps from a metamorphosed $\mathrm{Fe}-\mathrm{Mn}$ orebody in Långban, Sweden. It is associated with manganoan diopside, manganberzeliite, tilasite, svabite, hematite, calcite, barite (Långban, Sweden); hematite, muscovite (Sailauf, Germany). No other elements are present in significant proportion except $\mathrm{Si}$ substituting for As up to 0.08 apfu (Hansen et al., 1984a and b). It was described at several other localities. In Tennvatn pegmatite, Norway, bergslagite contains 0.226 apfu Si replacing As and 0.06 apfu Si replacing Be (per $4 \mathrm{O}+1 \mathrm{OH}$ formula unit, Raade et al., 2006).

Etymology: Named for the occurrence at Långban, in the Bergslagen region of Sweden.

Type locality: Långban, Värmland, Sweden. 
Location of holotype: University of Copenhagen, Copenhagen, Denmark; National Museum of Natural History, Washington, DC, USA, 162582.

Selected references: Hansen et al. (1984a, b).

\section{References}

Bačík, P., Fridrichová, J., Uher, P., Pršek, J., Ondrejka, M. (2014): Crystal chemistry of gadolinite-datolite group minerals. Can. Mineral., 52, 625-642.

Bakakin, V.V., Belov, N.V., Borisov, S.V., Solovieva, L.P. (1970): The crystal structure of nordite and its relationships to melilite and datolite-gadolinite. Am. Mineral., 55, 1167-1181.

Bastin, G.F. \& Heijligers, H.J.M. (1986a): Quantitative electron probe microanalysis of boron in some binary borides. in "Microbeam analysis", A.D. Romig Jr. \& W.F. Chambers, eds. San Francisco Press, Inc., California, 285-288.

Bastin, G.F. \& Heijligers, H.J.M. (1986b): Quantitative electron probe microanalysis of boron in binary borides. Internal Report Eindhoven University of Technology, Eindhoven, the Netherlands.

Bastin, G.F. \& Heijligers, H.J.M. (1991): Quantitative electron probe microanalysis of ultra-light elements (boron-oxygen). in "Electron probe quantification", K.F.J. Heinrich \& D.E. Newbury, eds. Plenum Press, New York, USA, 145-161.

Bayliss, P., Kaesz, H.D., Nickel, E.H. (2005): The use of chemicalelement adjectival modifiers in mineral nomenclature. Can. Mineral., 43, 1429-1433.

Baysal, O. \& Dilekoz, E. (1975): A study of bakerite. Bull. Miner. Res. Explor. Inst. Turkey, 84, 90-96.

Bellatreccia, F., Della Ventura, G., Cámara, F. (2006): Datolite: a new occurrence in volcanic ejecta (Pitigliano, Toscana, Italy) and crystal-structure refinement. Rend. Fis. Acc. Lincei, 17, 289-298.

Biscoe, J. \& Warren, B.E. (1930): The structure of euclase $\mathrm{HBeAlSiO}_{5}$. Z. Kristallogr., 86, 292-297.

Boiocchi, M., Callegari, A., Ottolini, L. (2006): The crystal structure of piergorite-(Ce), $\mathrm{Ca}_{8} \mathrm{Ce}_{2}\left(\mathrm{Al}_{0.5} \mathrm{Fe}^{3+}{ }_{0.5}\right)_{\Sigma 1}(\square, \mathrm{Li}, \mathrm{Be})_{2} \mathrm{Si}_{6-}$ $\mathrm{B}_{8} \mathrm{O}_{36}(\mathrm{OH}, \mathrm{F})_{2}$ : a new borosilicate from Vetralla, Italy, with a modified hellandite-type chain. Am. Mineral., 91, 1170-1177.

Brögger, W.C. (1890): Die Mineralien der Syenitpegmatitgänge der südnorwegischen Augit- und Nephelinsyenite. Z. Kristallogr. Mineral. B (Leipzig), 16, 1-663.

Burke, E.A.J. (2006): Mass discreditation of GQN minerals. Can. Mineral., 44, 1557-1560.

Cámara, F., Oberti, R., Ottolini, L., Della Ventura, G., Bellatreccia, F. (2008): The crystal chemistry of Li in gadolinite. Am. Mineral., 93, 996-1004.

Černá, I., Černý, P., Selway, J.B., Chapman, R. (2002): Paragenesis and origin of secondary beryllophosphates: beryllonite and hydroxylherderite from the Bep granitic pegmatite, southeastern Manitoba, Canada. Can. Mineral., 40, 1339-1345.

Černý, P. (1991): Rare-element granitic pegmatites. Part I: anatomy and internal evolution of pegmatite deposits. Geosci. Canada, 18, 49-67.

Černý, P. (2002): Mineralogy of beryllium in granitic pegmatites. in "Beryllium: mineralogy, petrology, and geochemistry", Reviews in Mineralogy and Geochemistry, Vol. 50, E.S. Grew, ed. Mineralogical Society of America, Chantilly, Virginia, 405-444.

Černý, P. \& Ercit, T.S. (2005): The classification of granitic pegmatites revisited. Can. Mineral., 43, 2005-2026.
Demartin, F., Pilati, T., Diella, V., Gentile, P., Gramaccioli, C.M. (1993): A crystal-chemical investigation of alpine gadolinite. Can. Mineral., 30, 127-136.

Demartin, F., Minaglia, A., Gramaccioli, C.M. (2001): Characterization of gadolinite-group minerals using crystallographic data only: the case of hingganite-(Y) from Cuasso al Monte, Italy. Can. Mineral., 39, 1105-1114.

Ding, X., Bai, G., Yuan, Z., Sun, L. (1981): Yttroceberysite, a new Ce-Be-rich silicate. Geol. Rev., 27, 459-466.

Ding, X., Bai, G., Yuan, Z., Liu, L. (1984): Hingganite [(Y,Ce) $\left.\mathrm{BeSiO}_{4}(\mathrm{OH})\right]$ : new data. Yanshi Kuangwu Ji Ceshi, 3, 46-48 (in Chinese).

Embrey, P.H. \& Hey, M.H. (1970): “Type” specimens in mineralogy. Mineral. Rec., 1, 102-104.

Foit, F.F. \& Gibbs, G.V. (1975): Refinement of $\mathrm{NiYb}_{2} \mathrm{Be}_{2} \mathrm{Si}_{2} \mathrm{O}_{10}$, a gadolinite-type structure. Z. Kristallogr., 141, 375-386.

Foit, F.F., Phillips, M.W., Gibbs, G.V. (1973): A refinement of the crystal structure of datolite, $\mathrm{CaBSiO}_{4}(\mathrm{OH})$. Am. Mineral., 58, 909-914.

Foord, E.E., Gaines, R.V., Crock, J.G., Simmons, W.B., Barbosa, C. P. (1986): Minasgeraisite, a new member of the gadolinite group from Minas Gerais, Brazil. Am. Mineral., 71, 603-607.

Gibson, S.J. \& Ehlmann, A.J. (1970): Annealing characteristics of metamict gadolinite from Rode Ranch, Texas. Am. Mineral., 55, 288-291.

Giles, W.B. (1903): Bakerite (a new borosilicate of calcium) and howlite from California. Mineral. Mag., 13, 353-355.

Grew, E.S. (1996): Borosilicates (exclusive of tourmaline) and boron in rock-forming minerals in metamorphic environments. in "Boron: mineralogy, petrology and geochemistry", Reviews in Mineralogy and Geochemistry, Vol. 33, E.S. Grew \& L.M. Anowitz, eds. Mineralogical Society of America, Chantilly, Virginia, 387-502.

Grew, E.S. (2002): Mineralogy, petrology and geochemistry of beryllium: an introduction and list of beryllium minerals. in "Beryllium: mineralogy, petrology, and geochemistry", Reviews in Mineralogy and Geochemistry, Vol. 50, E.S. Grew, ed. Mineralogical Society of America, Chantilly, Virginia, 1-76.

Grew, E.S., Locock, A.J., Mills, S.J., Galuskina, I.O., Galuskin, E. V., Hålenius, U. (2013): Nomenclature of the garnet supergroup. Am. Mineral., 98, 785-811.

Haidinger, W. (1828): On herderite, a new mineral species. Philos. Mag. Ann. Philos. New Ser., 4, 1-3.

Hansen, S., Fälth, L., Johnsen, O. (1984a): Bergslagite, a mineral with tetrahedral berylloarsenate sheet anions. Z. Kristallogr., 160, 73-80.

Hansen, S., Fälth, L., Petersen, O.V., Johnsen, O. (1984b): Bergslagite, a new mineral species from Långban, Sweden. Neues Jb. Miner. Mh., 1984, 257-262.

Harlow, G.G. \& Hawthorne, F.C. (2008): Herderite from Mogok, Myanmar, and comparison with hydroxyl-herderite from Ehrenfriedersdorf, Germany. Am. Mineral., 93, 1545-1549.

Hatert, F. \& Burke, E.A.J. (2008): The IMA-CNMNC dominantconstituent rule revisited and extended. Can. Mineral., 46, 717-728.

Hîrtopanu, P., Uduba, A.G., Scott, P. (2003): Minerals of the metamorphosed Mn-Fe deposits in Romania: old deposits, new species. Acta Mineral. Petrogr. Abstr. Ser. 1, 44.

Holtstam, D. \& Andersson, U.B. (2007): The REE minerals of the Bastnäs-type deposits, south-central Sweden. Can. Mineral., 45, 1073-1114. 
Ito, J. (1967): Synthesis of calciogadolinite. Am. Mineral., 52, 1523-1527.

Ito, J. \& Hafner, S.S. (1974): Synthesis and study of gadolinites. Am. Mineral., 59, 700-708.

Ito, T. \& Mori, H. (1953): The crystal structure of datolite. Acta Crystallogr., 6, 24-32.

Jambor, J.L., Roberts, A.C., Grice, J.D., Birkett, T.C., Groat, L.A., Zajac, S. (1998): Gerenite-(Y), $(\mathrm{Ca}, \mathrm{Na})_{2}(\mathrm{Y}, \mathrm{REE})_{3} \mathrm{Si}_{6} \mathrm{O}_{18} \cdot 2 \mathrm{H}_{2} \mathrm{O}$, a new mineral species, and an associated Y-bearing gadolinitegroup mineral, from the Strange Lake peralkaline complex, Québec-Labrador. Can. Mineral., 36, 793-800.

King, G.S.D. \& Sengier-Roberts, L. (1988): Drugmanite, $\mathrm{Pb}_{2}\left(\mathrm{Fe}_{0.78} \mathrm{Al}_{0.22}\right) \mathrm{H}\left(\mathrm{PO}_{4}\right)_{2}(\mathrm{OH})_{2}$ : its crystal structure and place in the datolite group. Bull. Minéral., 111, 431-437.

Klaproth, M.H. (1802): Beiträge zur chemischen Kenntniss der Mineralkörper 3. Rottmann, Berlin, 52.

- (1806): Chemische Untersuchung des Datoliths. Neues Allg. J. Chem., 6, 107-110.

Kozłowski, A. \& Dzieržanowski, P. (2007): Gadolinite from the Michalowice quarry, Karkonosze Massif, SW Poland. Mineral. Pol., 31, 185-188.

Kusachi, I., Henmi, Ch., Kobayashi, Sh. (1994): Chemical composition of bakerite from Fuka, Okayama Prefecture, Japan. Mineral. J., 17, 111-117.

Kutzschbach, M., Wunder, B., Rhede, D., Koch-Müller, M., Ertl, A., Giester, G., Heinrich, W., Franz, G. (2016): Tetrahedral boron in natural and synthetic HP/UHP tourmaline: evidence from Raman spectroscopy, EMPA, and single crystal XRD. Am. Mineral., 101, 93-104.

Levinson, A.A. (1966): A system of nomenclature for rare-earth minerals. Am. Mineral., 51, 152-158.

Lulu, X.M. \& Zhi-Zhong, P. (1986): Crystal structure of xinganite. Geochemistry, 5, 280-285.

Majka, J., Pršek, J., Budzyn, B., Bačík, P., Barker, A.K., Łodzinski, M. (2011): Fluorapatite-hingganite-(Y) coronas as products of fluid induced xenotime-(Y) breakdown in the Skoddefjellet pegmatite, Svalbard. Mineral. Mag., 75, 159-167.

Massanek, A., Rank, K., Weber, W. (1999): Die mineralogischen Sammlungen des Abraham Gottlob Werner. Lapis, 24, 21-31.

McGee, J.J. \& Anovitz, L.M. (1996): Electron probe microanalysis of geologic materials for boron. Rev. Mineral., 33, 771-788.

McGee, J.J., Slack, J.F., Herrington, C.R. (1991): Boron analysis by electron microprobe using $\mathrm{MoB}_{4} \mathrm{C}$ layered synthetic crystals. Am. Mineral., 76, 681-684.

Miyawaki, R. \& Nakai, I. (1996): Crystal chemical aspects of rare earth minerals. in "Rare earth minerals. Chemistry, origin and ore deposits", The Mineralogical Society Series, Vol. 7, A.P. Jones, F. Wall, C.T. Williams, eds. Chapman \& Hall, London, $21-40$.

Miyawaki, R., Nakai, I., Nagashima, K. (1984): A refinement of the crystal structure of gadolinite. Am. Mineral., 69, 948-953.

- - - - - (1985): Structure of homilite, $\mathrm{Ca}_{2.00}\left(\mathrm{Fe}_{0.90} \mathrm{Mn}_{0.03}\right)$ $\mathrm{B}_{2.00} \mathrm{Si}_{2.00} \mathrm{O}_{9.86}(\mathrm{OH})_{0.14}$. Acta Crystallogr., C41, 13-15.

Miyawaki, R., Nakai, I., Nagashima, K., Okamoto, A., Isobe, T. (1987): The first occurrence of hingganite, hellandite and wodginite in Japan. J. Mineral. Soc. Jpn. (Kobutsugaku Zasshi), 18, 17-30 (in Japanese with English abstract).

Miyawaki, R., Matsubara, S., Yokoyama, K., Okamoto, A. (2007): Hingganite-(Ce) and hingganite-(Y) from Tahara, Hirukawamura, Gifu Prefecture, Japan: the description on a new mineral species of the Ce-analogue of hingganite-(Y) with a refinement of the crystal structure of hingganite-(Y). J. Mineral. Petrol. Sci., 102, 1-7.

Momma, K. \& Izumi, F. (2011): VESTA 3 for three-dimensional visualization of crystal, volumetric and morphology data. $J$. Appl. Crystallogr., 44, 1272-1276.

Mrose, M.E. \& von Knorring, O. (1959): The mineralogy of väyrynenite, $(\mathrm{Mn}, \mathrm{Fe}) \mathrm{Be}\left(\mathrm{PO}_{4}\right)(\mathrm{OH})^{*}$. Z. Kristallogr., 112, 275-288.

Nakai, T. (1938): On calciogadolinite, a new variety of gadolinite found in Tadachi, Nagano. Bull. Chem. Soc. Jpn., 13, 591-594.

Ottolini, L., Cámara, F., Hawthorne, F.C., Stirling, J. (2002): SIMS matrix effects in the analysis of light elements in silicate minerals: comparison with SREF and EMPA data. Am. Mineral., 87, 1477-1485.

Paijkull, S.R. (1876): Homilit, ett mineral från Brevig i Norge. Geol. Fören. Stock. För., 3, 229-232.

Palache, C., Berman, H., Frondel, C. (1951): Dana's system of mineralogy, 7th edn., Vol. II, John Wiley \& Sons, New York, $363 \mathrm{p}$.

Pasero, M., Kampf, A.R., Ferraris, C., Pekov, I.V., Rakovan, J., White, T.J. (2010): Nomenclature of the apatite supergroup minerals. Eur. J. Mineral., 22, 163-179.

Pekov, I.V., Voloshin, A.V., Pushcharovskii, D.Yu., Rastsvetaeva, R. K., Chukanov, N.V., Belakovskii, D.I. (2000): New data on calcybeborosilite-(Y) $(\mathrm{REE}, \mathrm{Ca})_{2}(\mathrm{~B}, \mathrm{Be})_{2}\left(\mathrm{SiO}_{4}\right)_{2}(\mathrm{OH}, \mathrm{O})_{2}$. Vestn. Mosk. Univ. Geol., 55, 62-70.

Pemberton, H.E. (1971): Type locality for bakerite. Am. Mineral., 56, 1109-1110.

Penfield, S.L. (1894): On the crystallization of herderite. Am. J. Sci., 147, 329-339.

Perchiazzi, N., Gualtieri, A.F., Merlino, S., Kampf, A.R. (2004): The atomic structure of bakerite and its relationship to datolite. Am. Mineral., 89, 767-776.

Pezzotta, F., Diella, V., Guastoni, A. (1999): Chemical and paragenetic data on gadolinite-group minerals from Baveno and Cuasso al Monte, southern Alps, Italy. Am. Mineral., 84, 782-789.

Pierini, G. (2004): Homilite in un proietto vulcanico a Tre Croci di Vetralla (VT). Micro (notizie mineralogiche), 2004, 5-12.

Povarennykh, A.S. \& Dusmatov, V.D. (1970): Infrared absorption spectra of new minerals from alkaline pegmatites of central Asia. Konst. Svoistva Mineralov, Akad. Nauk Ukr. S.S.R., Respub. Mezhvedom. Sb., 4, 3-9.

Pršek, J., Ondrejka, M., Bačík, P., Budzyn, B., Uher, P. (2010): Metamorphic-hydrothermal REE minerals in the Bacúch magnetite deposit, Western Carpathians, Slovakia: (Sr,S)-rich monazite-(Ce) and Nd-dominant hingganite. Can. Mineral., 48, 81-94.

Raade, G., Kolitsch, U., Husdal, T.A. (2006): Si-rich bergslagite from a granitic pegmatite at Tennvatn, north Norway. GFF, 128, 65-68.

Rinaldi, R., Gatta, G.D., Angel, R.J. (2010): Crystal chemistry and low-temperature behavior of datolite: a single-crystal X-ray diffraction study. Am. Mineral., 95, 1413-1421.

Sabina, A.P. (1978): Some new mineral occurrences in Canada. Geological Survey of Canada, Paper 78-1A, 253-258.

Schnorrer, G. \& Schäfer, H. (1999): Drugmanit, $\mathrm{Pb}_{2}\left(\mathrm{Fe}^{3+}, \mathrm{Al}\right)[\mathrm{OH} /$ $\left.\mathrm{PO}_{4}\right]_{2} \cdot \mathrm{H}_{2} \mathrm{O}$, ein drittes Vorkommen aus der Eifel (Grube Neue Hoffnung). Der Aufschluss, 50, 225-228. 
Segalstad, T.V. \& Larsen, A.O. (1978): Gadolinite-(Ce) from Skien, southern Oslo region, Norway. Am. Mineral., 63, 188-195.

Semenov, E.I., Dusmatov, V.D., Samsonova, N.S. (1963): Yttriumberyllium minerals of the datolite group. Kristallografiya, $\mathbf{8}$, $667-679$.

Shannon, R.D. (1976): Revised effective ionic radii and systematic studies of interatomic distances in halides and chalcogenides. Acta Crystallogr., A32, 751-767.

Škoda, R., Plášil, J., Čopjaková, R., Novák, M., Jonsson, E., Vašinová Galiová, M., Holtstam, D. (2016): Gadolinite-(Nd), IMA 2016-013. CNMNC Newsletter No. 32, August 2016, page 916. Mineral. Mag., 80, 915-922.

Uher, P., Ondrejka, M., Konečný, P. (2009): Magmatic and postmagmatic Y-REE-Th phosphate, silicate and Nb-Ta-Y-REE oxide minerals in A-type metagranite: an example from the Turčok massif, the Western Carpathians, Slovakia. Mineral. Mag., 73, 1009-1025.

Van Tassel, R., Fransolet, A.-M., Abraham, K. (1979): Drugmanite, $\mathrm{Pb}_{2}\left(\mathrm{Fe}^{3+}, \mathrm{Al}\right)\left(\mathrm{PO}_{4}\right)_{2}(\mathrm{OH}) \cdot \mathrm{H}_{2} \mathrm{O}$, a new mineral from Richelle, Belgium. Mineral. Mag., 43, 463-467.

Volborth, J. (1954): Väyryneniiti, $\mathrm{BeMnPO}_{4}(\mathrm{OH}, \mathrm{F})$. Geologi, 6,7 .
Voloshin, A.V., Pakhomovskii, J.A., Menshikov, I.P., Povarennykh, A.S., Matvienko, E.N., Iakubovich, O.V. (1983): Hingganite (Yb), a new mineral from the amazonite pegmatites of the Kola-peninsula. Dokl. Akad. Nauk SSSR, 270, 1188-1192.

Voloshin, A.V., Pakhomovskii, J.A., Sorokhtina, N.V. (2002): Chemical composition of the gadolinite-group minerals from the amazonite pegmatites in the Kola Peninsula. Vestnik Murmanskiy Gosudarstvennyy Tekhnicheskiy Universitet, 5, 61-70 (in Russian).

Yakubovich, O.V., Matvinenko, E.N., Voloshin, A.V., Simonov, M.A. (1983): The crystal structure of hingganite-( $\mathrm{Yb})$, $\left(\mathrm{Y}_{0.51} \mathrm{TR}_{0.36} \mathrm{Ca}_{0.13}\right) \mathrm{Fe}_{0.065} \mathrm{Be}\left[\mathrm{SiO}_{4}\right](\mathrm{OH})$. Kristallografiya, 28, 457-460.

Zaccarini, F., Morales-Ruano, S., Scacchetti, M., Garuti, G., Heide, K. (2008): Investigation of datolite $\mathrm{CaBSiO}_{4}(\mathrm{OH})$ from basalts in the Northern Apennines ophiolites (Italy): genetic implications. Chem. Erde, 68, 265-277.

Received 11 October 2016

Modified version received 23 January 2017

Accepted 27 March 2017 